\title{
LAS DEPENDENCIAS PERSONALES Y LAS PRESTACIONES ECONÓMICAS EN LA EXPANSIÓN FEUDAL EN LA CATALUÑA NUEVA (SIGLO XII)
}

\author{
MARIA BONET DONATO \\ Universidad Rovira i Virgili (Tarragona)
}

RESUMEN: El estudio analiza la sociedad feudal en las tierras y la época de la gran expansión catalana de mediados del siglo XII, destacando las relaciones de dependencia personales y su expresión en las prestaciones económicas, que fueron los pilares de dicho entramado social. La transformación de las fórmulas de sujeción personal como consecuencia de las conquistas dejó atrás un modelo en el que el poder se repartía y las funciones militares lo justificaban, introduciéndose otro en el que los señores consolidaron su potestad dominical y extendieron las vinculaciones personales a otros sectores sociales. De la jerarquización entre los señores y de la atomización del poder territorial se pasó a la centralización de la autoridad señorial, con nuevas manifestaciones como la condal, la urbana o la de órdenes regulares, en sintonía con la centralización de los poderes territoriales. Se desarrollaron nuevos principios pacificadores o de justicia, se simplificó el sistema de prestaciones, y surgieron nuevas clases sociales subalternas, que contribuyeron a imponer la organización feudal en las tierras conquistadas y a consolidar su recomposición en regiones anteriormente feudalizadas.

Palabras clave: Historia social. Cataluña Nueva. Siglo XII. Poder dominical. Relaciones personales de dependencia. Rentas.

ABSTRACT: This article analyses the feudal society in the territories and in the age of the great Catalan expansion in the middle of the 12th century, it focuses on the relationships of personal dependence and their economic manifestation in rents, as the basis of this social organisation. The transformation of the forms of personal dependences as a result of the conquests meant that a system where power, shared and supported by military activities was replaced by one where the lords consolidated their seigneurial power and extended dependency to other sections of society. The lords' hierarchical structure and the compartmentalization of territorial power were replaced by increased lordly authority, as exemplified by new manifestations in religious orders, urban and count's powers. New forms of pacification and justice were consequently developed, the rental system was simplified and subaltern social classes emerged, which all 
contributed to the imposition of the feudal society in the occupied lands and to their consolidations in the regions previously under feudal control.

KEY WORDS: New Catalonia. Twelfth century. Seigneurial power. Relationships of personal dependency. Rents.

\section{PRESENTACión}

La expansión de los condados catalanes en el siglo XII significó la feudalización de la Cataluña Nueva, definiéndose un entramado social basado en relaciones de dependencia personal, que comprometían prestaciones económicas. La nueva realidad feudal de las tierras conquistadas difirió de la de los lugares de origen, aunque había surgido de la extensión de sus fórmulas organizativas. Ya en el siglo XIII, esta dualidad se reflejó en la distinción entre la Cataluña Vieja y la Nueva, a un lado y otro del río Llobregat, que todavía permite singularizar las respectivas formas de ordenación social. Tal y como ha analizado M. A. García de Cortázar a escala peninsular, las regiones incorporadas a la órbita cristiana tras la toma de Toledo (1085) se organizaron según el modelo procedente de los territorios al norte, pero adquiriendo unas peculiaridades propias, que mostraban la maduración de la sociedad feudal ${ }^{1}$.

Los señores se impusieron en las tierras de la expansión catalana, y convertidos en los nuevos propietarios ordenaron y sometieron a las poblaciones. El reparto de poderes entre ellos y la sujeción del campesinado se alcanzó mediante la fijación de vinculaciones personales y obligaciones económicas. De este modo las relaciones de dependencia personal les permitieron consolidar el dominio territorial y social que les proporcionaba el excedente agrario.

El conocimiento de las prestaciones campesinas ha sido un tema fundamental en estudios sobre el funcionamiento de la sociedad en la plena edad media, puesto que son la manifestación o la razón de la dominación de los sectores productores por parte de los señores. Sin embargo, el examen de la renta feudal resulta insuficiente a la hora de explicar las vinculaciones sociales, porque los elementos «extraeconómicos» estructuraban o reforzaban las llamadas "relaciones de producción feudal». Desde lo jurídico hasta lo ideológico, se definían y amparaban los lazos del campesinado con los señores, o de estos entre sí ${ }^{2}$. Con todo y pese al desarrollo «extraeconómico» de las dependencias interpersonales, tuvieron una manifestación o expresión económica, mediante presta-

${ }^{1}$ García De Cortázar, M.A.: La sociedad rural en la España medieval, Madrid, 1988, pp. 55-64.

2 MANZANO, E.: «Relaciones sociales en sociedades precapitalistas: una crítica al concepto «modo de producción tributario», en Hispania (Madrid) LVIII/3 200 (1998), pp. 881-913. En este brillante artículo, el autor destaca la importancia y la especificidad de las relaciones de dependencia para comprender las sociedades medievales, subrayando la trascendencia de los factores extraeconómicos. Además advierte de la fragilidad de la caracterización de las sociedades o formaciones sociales precapitalistas únicamente a partir de los análisis del debate renta/tributo. 
ciones o contraprestaciones. Por ello, mostraremos como las sujeciones personales y las exigencias económicas eran inseparables cuando se trataba de definir la posición de cada sujeto en la compleja red de las relaciones plenomedievales.

Distintos planteamientos historiográficos han abordado el tema de las vinculaciones y los deberes en la sociedad feudal, y significativamente se han centrado en el campesinado del Occidente medieval o de los reinos peninsulares. Sin embargo, en ocasiones, los resultados son parciales o dispares, fruto de las propias propuestas teóricas o metodológicas y de la complejidad de las fuentes. En este sentido, se echa en falta un estudio completo y renovador sobre la evolución de las dependencias sociales catalanas en la Edad Media ${ }^{3}$. Esto no es óbice para destacar las importantes contribuciones de Pierre Bonnassie, Paul Freedman, Josep Maria Salrach, y especialmente el análisis ya clásico pero imprescindible de Eduardo Hinojosa, que son puntos de partida fundamentales ${ }^{4}$.

Buena parte de las principales aportaciones sobre esta temática se han centrado en la documentación de la Cataluña Vieja, aunque a veces se hayan generalizado algunas conclusiones al conjunto del territorio catalán. En cambio, la publicación en las últimas décadas de monografías y fuentes sobre la Cataluña Nueva han permitido avanzar en algunas cuestiones*5. Con todo, todavía exis-

${ }_{3}$ La obra de M.A. García de Cortázar, op. cit., es una referencia fundamental sobre las relaciones sociales en la Hispania medieval, donde se explican los cambios relativos a un marco temporal amplio y las particularidades regionales. Todavía no existe un balance de estas características sobre el ámbito catalán, como apunta de manera indirecta, BIssON, T.: Tormented voices. Power, Crisis and Humanity in Rural Catalonia 1140-1200, Harvard, 1998, p. V.

${ }^{4}$ HinOJOSA, E.: «El régimen señorial y la cuestión agraria en Cataluña durante la Edad Media», en Obras de Don Eduardo de Hinojosa, II, Madrid, 1955 (1 $1^{\text {a } 1905), ~ p p . ~ 35-328 . ~ M a ́ s ~ a d e l a n t e ~}$ se introducirán las referencias bibliográficas de los mencionados autores relacionadas con los temas tratados.

*5 Cabe destacar el carácter pionero de las publicaciones de J.M. Font i Rius, y especialmente la edición de documentos: Cartas de población y franquicia de Cataluña, desde ahora Cartas, BarcelonaMadrid, I, 1969 y II, 1983. Otras colecciones diplomáticas permiten abordar esta aproximación sobre las dependencias personales: Altisent, A (ed.): Diplomatari de Santa Maria de Poblet, anys 960-1177, en adelante Diplomatari, Barcelona, 1993; MIQUEL, F.: Liber feudorum maior, Barcelona, 1945; UDINA, F., (ed.): El Ilibre Blanch de Santes Creus, Barcelona, 1947 en adelante LBSC; SANS, J.M. (ed.): Colllecció diplomática de la casa del Temple de Barbera, (945-1212), en adelante Col.lecció, Barcelona, 1997; VIRGILI, A. (ed.): Diplomatari de la catedral de Tortosa (1062-1193), Barcelona, 1997 en adelante Diplomatari Tortosa; SAROBE, R. (ed.): Col.lecció diplomática de la casa del temple de Gardeny (1070-1200), en adelante Col.lecció Gardeny, Barcelona, 1998; Bofarull, P. (ed.): Colección de documentos inéditos de la Corona de Aragón, IV en adelante Codoin, Barcelona, 1848; Pons, J.: Cartulari de Poblet. Edició del Manuscrit de Tarragona, Barcelona, 1938 desde ahora Cartulari de Poblet. No podemos ofrecer un estado de la cuestión sobre la historiografía reciente referida a la Cataluña Nueva medieval, aunque recordamos las primeras historias locales completas por tratarse de obras básicas: LladonOSA, J.: Història de Lleida, Tàrrega, 1972-4; especialmente MORERA, E.: Tarragona Cristiana, I y II, Tarragona 1981 ( $\left.1^{\text {a }} 1897\right)$ e incluso la discutible de BAYERRI, E.: Historia de Tortosa y su comarca, VII, Tortosa, 1957. Se ha adoptado el criterio de usar la toponimia en catalán, y la mayoría de los antropónimos, salvo aquellos que tienen una castellanización consolidada en fuentes y bibliografía. 
te un desnivel importante en el conocimiento del desarrollo de la sociedad feudal y concretamente de las características y evolución de las relaciones interpersonales de estas dos regiones de Cataluña, que ha animado esta aproximación centrada en los territorios incorporados o afectados por la expansión del siglo XII.

Las peores condiciones de la vida campesina en la Cataluña Vieja han servido para singularizar las fórmulas de su organización social. Este tópico se ha ido disipando al conocerse la exigencia ocasional de «malos usos», y sobre todo las formas de sometimiento del campesinado en la Cataluña Nueva que han relativizado la importancia de la condición remensa ${ }^{6}$. Sin embargo, resulta elocuente que las diferencias se reconociesen a mediados del XIII, cuando culminaba la expansión catalana en tierras valencianas. Las duras actuaciones señoriales en la Cataluña Vieja intentaban contener un proceso migratorio prolongado en el tiempo, mientras que algunas intervenciones de los señores de la Nueva pretendían ser «benefactoras» para sellar los reajustes poblacionales, sobre todo en el ámbito meridional catalán. De manera que la «competencia» ejercida por las tierras recién conquistadas a los intereses dominicales, se contestaba de forma distinta, casi antagónica en las dos regiones, aunque la finalidad fuese la sujeción del campesinado. Este esquema dinámico y variado de las acciones señoriales, condicionadas por los nuevos horizontes, se puede trasladar a los ámbitos y época que estudiamos.

En definitiva, en estas páginas se plantea la comprensión de la sociedad feudal en tierras y en tiempos de la primera gran expansión catalana a partir de la caracterización de las vinculaciones personales o de las obligaciones económicas, que son aspectos fundamentales de las relaciones entre los señores y de estos con los campesinos? ${ }^{7}$ Las dependencias personales se estudian de forma global, desdibujando precisamente la separación entre las de los ámbitos de poder y las orientadas a la explotación socioeconómica, y a su vez realzando su expresión económica. La comparación entre varias regiones, afectadas de forma distinta por los precedentes o la ocupación cristiana, permiten apuntar las causas de la transformación de las fórmulas de sujeción personal en plena extensión del feudalismo. Además el análisis muestra que si bien las conquistas no alumbraron una nueva sociedad, impusieron la recomposición de las dependencias feudales, tanto en la vanguardia como en la retaguardia de la Cataluña Nueva, que prefiguraban la ordenación social pleno y bajo medieval.

${ }^{6}$ La más temprana o trascendente caracterización entre sendas regiones fue la de Pere Albert, quien a mediados del XIII distinguía las condiciones de vida de los campesinos de la Cataluña Vieja, más dependientes que los de la Nueva, donde podían vivir y casarse a voluntad, FreEDMAN, P.: «The Llobregat as a Frontier in the Thirteenth Century» en Miscel.lània en bomenatge al P. Agustí Altisent, Tarragona, 1991, pp. 109-117/ 111.

7 El balance se ciñe a un elenco significativo de asuntos o casos, enmarcados en una cronología que va desde la década de los treinta a la de los setenta del siglo XII, con alguna excepción. 


\section{LA CONSOLIDACIÓN DE LOS SEÑORES FEUDALES EN EL TERRITORIO Y LA FIJACIÓN DE LAS DEPENDENCIAS PERSONALES}

La organización de la clase feudal en cada territorio respondía a cómo se establecieron o vincularon sus miembros y explica las relaciones que trabaron con los sectores productores. El término feudalización engloba sendos procesos indisociables y describe la formación de una sociedad vertebrada por vínculos de dependencia, ajena a la diferenciación jurídica de las relaciones entre los elementos aristocráticos y de las de ellos con los campesinos. Sin embargo, el reconocimiento de las instituciones propias de los señores ayuda a esclarecer quienes eran, y así evitar que se confundan con otros sectores sociales como sucede en algunos estudios; si bien es más difícil establecer la condición socioeconómica de los sectores no privilegiados.

La implantación del feudalismo en la Cataluña Nueva se desarrolló en distintas etapas cronológicas, que unido a las características de las regiones condicionaron los mecanismos desplegados por los señores para consolidar su dominio territorial. En el siglo X — sobre todo a finales - se había iniciado el proceso feudalizador en la Marca del condado de Barcelona, en las actuales comarcas de Anoia, Penedés, Garraf y Alt Camp. Este avanzó durante la primera mitad del XI en el Penedés, en el Alt Camp y en la Conca de Barberà, introduciéndose en las cercanías de Tarragona, y se consolidó en la segunda mitad del XI. Paralelamente, en el condado de Urgell la expansión progresaba durante el siglo XI, alcanzando el Mascançà a finales de siglo, aproximándose $\mathrm{y}$ rodeando la ciudad de Balaguer, tomada en 1105. Luego en el XII, se produjo la culminación del proceso con la feudalización del territorio de Tarragona en la década de los treinta y finalmente de las tierras de Tortosa y Lleida tras sus importantes conquistas -1148 y 1149 respectivamente- 8 .

En estas regiones los acuerdos feudovasalláticos establecieron las redes de las relaciones y ciertas jerarquías del poder entre los aristócratas de la zona. Los lazos de dependencia respondían a la búsqueda de aliados, al sometimiento de rivales o de señores menores, siendo una extensión de la potestad dominical. Sin embargo se produjo una rápida evolución y propagación de variantes de estos pactos, en la que se pasó del reparto del poder o del territorio al de los beneficios y a la fijación de las dependencias. A la fórmula clásica de la convenientia, se añadían compromisos militares, donaciones con retención de dominio o infeudaciones para definir las relaciones de adhesión o sujeción entre señores y vasallos. La concesión de cartas de población o incluso de unidades de explotación campesinas culminaban la fijación de vínculos de dependencia per-

${ }^{8}$ Como introducción a las etapas y características de la expansión, SABATÉ, F.: «L'expansió territorial de Catalunya (segles IX-XII): ¿conquesta o repoblació?», Lleida, 1996. BONNASSIE, P.: «Sur la formation du féodalisme catalan et la première expansion (jusqu'à 1150 environ)», en Estudi General, (Girona) 4-5 (1985-86), pp. 7-26, atiende brevemente a la primera fase expansiva, aunque es demasiado teórico para el análisis desarrollado. 
sonal con sectores sociales no privilegiados, que resultaban de la disponibilidad de las tenencias campesinas?.

Hubo préstamos significativos entre las distintas modalidades documentales, en los contenidos o en las formas, muy visible en las derivaciones de las convenientiae, y además se produjo la proliferación o redefinición de algunas fórmulas contractuales como las «cartas de población», las donaciones, o los establiments agrarios $^{10}$. La evolución de los instrumentos era el resultado de los cambios en los mecanismos señoriales de la organización del territorio. En este sentido, el desarrollo o la diversificación de las relaciones de dependencia feudales abrió el camino a otras pactadas entre los privilegiados y los sectores emergentes de los no privilegiados, que se reflejó en la difusión de fórmulas como la del juramento de fidelidad, que desde el siglo XII, y de forma muy clara en el XIII prestaban al señor miembros no aristocráticos de localidades o dominios.

Los usatges de Barcelona confirman el requerimiento del juramento de fidelidad a todos los grupos sociales a mediados del XII, siguiendo la cronología de P. Bonnassie, y revelan el sentido del compromiso exigido a unos y otros. En el usatge 50 se pedía el juramento al señor por parte de omnes homines, precisándose a los caballeros y los campesinos, aunque el 48 con el mismo encabezamiento omnes homines se reclamaba el juramento escrito y sagrado a la «potestad» sólo a la clase caballeresca. Las diferencias del articulado son explicativas del significado de sendos juramentos, mientras que la reivindicación a los vasallos y el campesinado respondía a la dependencia jurisdiccional al señor, la de los sectores aristocráticos se fundaba en la vinculación a la potestad, o el poder condal. Únicamente en este caso el convenio comprometía al «honor», propiedad o feudo, y su disponibilidad quedaba supeditada a la fidelidad sagrada a la autoridad ${ }^{11}$.

9 En alguna ocasión se han identificado infeudaciones con cartas de población o incluso con establecimientos agrarios. Precisamente J.M. Font Rius incorpora documentos destinados a la fijación de dependencias vasalláticas en la edición de cartas de población, justificando «la legitimidad» de la inclusión puesto que suponían la repoblación del lugar y porque la concesión a una sola persona se debía a la dificultad de repoblar con un llamamiento general, op. cit., II, 1983, pp. 157 y 159. El autor observa que dichas donaciones podían corresponder a beneficios a cambio de servicio militar, aunque insiste una vez más en su carácter repoblador. No obstante el objeto de la donación de beneficios a vasallos era consolidar la dependencia, especialmente la militar y garantizar el funcionamiento del dominio, prevaleciendo este objetivo a la actividad «repobladora» en un sentido estricto.

${ }^{10}$ La proximidad de documentos como la dotación de feudo o la concesión de precaria antes del siglo XII fue señalada por E. Hinojosa, para quien no había diferencia esencial entre ellos. Con todo, las variaciones entre estas dos fórmulas hablan de beneficiarios de distintas condiciones sociales puesto que en la primera se exigía el compromiso militar y en la segunda el censo, op. cit., p. 96.

11 Valls, F.: Los Usatges de Barcelona, Málaga, 1984, p. 85, la exigencia del juramento a tenor de la jurisdicción se desprende de: sicut ipsi eis judicare fecerint juste in placitis (n. 50). La vinculación de la aristocracia con el conde estaba revestida de más solemnidad y sujeta a un mayor control que en otras manifestaciones de dependencia al señor, puesto que garantizaba los derechos del señor de señores de forma primordial como en otros artículos del mencionado texto legal. 
Estas vinculaciones eran el resultado del fortalecimiento de los poderes señoriales, que además de sellar los compromisos con sus pares, o incluso rivales, se aseguraban por distintas vías la «fidelidad» del resto de la población sujeta a su jurisdicción. Esto no obsta, para que otros grupos sociales, algunos no aristocráticos, como las oligarquías rurales afianzasen una posición subalterna, claramente consolidada en los siglos venideros.

Las pautas de la feudalización variaron según los territorios y la cronología, y se distinguen al menos dos ámbitos, uno caracterizado por el impulso señorial y con manifestaciones de mayor conflictividad en los extremos de la Marca o en el territorio de Tarragona, y otro en las regiones de Tortosa, Lleida e incluso Siurana, donde el proceso fue dirigido por el conde de Barcelona, aunque evidentemente marcado por la realidad andalusí preexistente. Asimismo se pueden fijar dos etapas del fenómeno feudalizador, una desde los años 30 en la que se redefinieron o fijaron las relaciones entre los poderes, que fue seguida por otra desde la segunda mitad del siglo XII, cuando los señores destacados afianzaron su dominio en todos los sentidos. Así frente al sistema de «delegación» del poder o de repartimiento manifiesto, sobre todo en la primera mitad del siglo, se revelaron las iniciativas de los señores de concentración del patrimonio o de reforzamiento de su potestad. Esto explicaría la proliferación de concesiones de las cartas de población desde la segunda mitad del siglo XII y durante el siglo siguiente, puesto que sirvieron para asegurar el control señorial en el territorio mediante nuevos interlocutores y a través de formas distintas, aunque cercanas, a los compromisos feudovasalláticos.

\subsection{Las estrategias señoriales en las Marcas en los prolegómenos y tras la gran expansión}

Entre las décadas de los años 30 y 50, algunos señores destacados, o a veces los condes de las zonas cercanas a la frontera persiguieron un mayor control o explotación del territorio y para ello fijaron dependencias vasalláticas mediante la concesión o confirmación de feudos. La inminencia de un posible ataque cristiano, y de forma muy clara en la región periférica de la ciudad de Lleida, intensificó el apuntalamiento de enclaves y personas fieles en la zona avanzada de las Marcas de los condados de Urgell o Barcelona. La conquista de Tortosa fue definitivamente un revulsivo en las iniciativas feudalizadoras desde Tarragona, o en otros lugares, y además conllevó un proceso de ocupación innovador conducido por Ramón Berenguer IV, que sería seguido tras las otras empresas militares.

En los extremos de las Marcas, los pactos feudovasalláticos comprometieron las prestaciones militares de los vasallos y consignaron el reparto de rentas entre señores y vasallos, poniéndose de manifiesto la interrelación entre la dependencia personal y las prestaciones económicas ${ }^{12}$. El señor dotaba al benefi-

${ }^{12}$ Se seguía la fórmula de las convenientiae del siglo XI, donde el reparto de las rentas era un elemento fundamental, que servía para la afirmación del poder señorial y la consolidación de la 
ciario de un dominio con una importante participación en las rentas para implicarlo en su captación, con lo que garantizaba la complicidad del dependiente en la percepción de la renta feudal puesto que incentivaba las tareas de vigilancia y del cobro.

Entre las rentas, jurisdiccionales y territoriales, que se repartían el señor y el beneficiario del feudo, el diezmo - o décima-, tenía un trato singular, e incluso se le asignaba una proporción distinta al resto de estas en la retención dominical. Esto se constata en la división tripartita de Conesa de 1130, en la que el señor retenía la tercera parte del diezmo y la mitad de las rentas al infeudarlo a Bernat Sinfré, quien al encomendar el lugar se reservó la cuarta parte del diezmo, los placitos — derechos por los pleitos—, obteniendo el vasallo las stachamenta — garantías judiciales_-13.

El reparto de los beneficios económicos concurrió con la división del poder, en sus máximas expresiones, militar y judicial, y los vasallos quedaron integrados en las tareas militares como las guaites — vigilacia_, las huestes, la defensa o la contribución en las fortificaciones. Incluso se llegó a condicionar el nivel de cumplimiento militar al valor del feudo, como en la concesión del Tallat ${ }^{14}$. El

relación de dependencia. Sobre los tipos de partición en el siglo XI, véase BONNASSIE, P.: «Les conventions feódales dans la Catalogne du XI siècle», en Les structures sociales de l'Aquitanie, du Languedoc et de l'Espagne au premier age féodale, París, 1969, pp. 186-219 y Catalunya mil anys enrera, II, Barcelona, 1981, pp. 63-71. El autor explica la asociación del castellano a los beneficios del señorío banal por su papel como gestor, y la implicación de los vasallos —castlans - en la percepción de las rentas porque ejercían un control más operativo que el señor, p. 62. Para la localización de los topónimos que aparecen en el texto, como Conesa, véase el mapa relativo a la expansión feudal: dominios infeudados y localidades dependientes.

${ }_{13}$ No vamos a entrar en la problemática sobre si eran diezmos o la décima, aunque algunos análisis muestran que eran diezmos, e incluso ocasionalmente se asociaba a las primicias Diplomatari, p. 93-. Para Conesa, Diplomatari, pp. 76-77 y un reparto parecido en Penelles d'Algareix, Diplomatari, pp. 106-7 (1147) y p. 110 (1148); que se corresponden a la división tripartita difundida desde la segunda mitad del siglo XI, BonNASSIE, P.: Catalunya, pp. 66-67. En la infeudación del castillo del Tallat del 1147, el beneficiario obtenía la mitad del diezmo y las stachamenta, medietatem placitorum omnium et exituum et iusticiarum, ac tertiam partem pernarum atque adempramenta et servitia sicut alii castelani ipsius terre habent in suis castris..., Diplomatari, p. 106, o en la concesión del castillo de Montmur, los señores retenían la mitad del diezmo y la tercera parte del resto de rentas, Cartas, pp. 103-4 (1146). En el Tallat se apuntan unas condiciones generales de participación en las rentas para quienes regentaban castillos o castlans, aunque en la región se documentan otros repartos. La necesidad de los señores de asegurar la satisfacción de las garantías judiciales, las stachamenta, explica que las librasen por completo a los castlans, quienes tenían la capacidad operativa in situ como en Conesa, el Tallat u otros lugares.

${ }^{14}$ En la infeudación de Conesa se exigían tareas de vigilancia y si guerra habuerit huestes y cabalgadas o en la de Milmanda el servicio de «guaitas», Diplomatari, pp. 108-109, y en las de Bellester, Almenara o Tallat la construcción de la fortificación, mientras que en Bellcaire la defensa - estas referencias documentales se indican más adelante- El vasallo del Tallat precisaba que cuando se conociese el valor de su honor, una vez edificado y poblado, correspondería al señor en ...hostes et servitia secundum valorem illius honoris. 
señor se aseguraba la dependencia y el cumplimiento o cobro de prestaciones y el vasallo desplegaba derechos en las fuentes del poder dominical a través de estos pactos.

En los prolegómenos del gran avance cristiano, la búsqueda de fidelidades unida a las exigencias militares coincidió, a veces, con la reclamación de reconstruir torres o construir fortalezas o castillos, y durante el proceso afloraron rivalidades señoriales. El conde de Urgell y otros señores querían afianzar sus posiciones al infeudar torres o encargar su reconstrucción en el Mascançà, -Pla d'Urgell - y lugares cercanos a Lleida. La preocupación de fortificar la región ante la proximidad del ataque a Lleida, se manifestó en la concesión del conde de Urgell de unam turrim destructam en Bellcaire a varias personas en 1139 para edificar una fortaleza. Además, les libró la cuarta parte de los diezmos para defenderse de paganos y otros «malvados», mientras durase la fortificación y hasta que se produjese la conquista de la mencionada ciudad andalusí, incentivando las prestaciones vasalláticas al menos temporalmente. La identificación de los musulmanes con otros adversarios cristianos como enemigos potenciales es reveladora y apuntaría a la conflictividad señorial en el lugar ${ }^{15}$.

En esta zona, las torres habían sido centros de explotación agraria musulmana y permanecieron como el centro del hábitat cristiano o del término castral dependiente. La continuidad de su valor referencial se corresponde con el mantenimiento de formas de organización patrimonial o del territorio andalusí por parte de los conquistadores cristianos ${ }^{16}$. Sin embargo, es posible observar como la importancia y la trascendencia que las torres tuvieron en los primeros tiempos de la feudalización en las tierras de Lleida, se oscurece en las comarcas catalanas del Ebro en el período de la conquista, según se analiza en el apartado 1.3.

15 Cartas, pp. 93-94, y Diplomatari, pp. 92-93.

16 La identificación de los distritos castrales con las torres en el ámbito del Mascançà explica que muchas lindes se fijasen en las torres, e incluso se precisaba in termino de turrim como en la de Torre Faneca, colindante con otras tres, Diplomatari, p. 97 o la de Bellester con la de Falcons y Berenguer Bertrà, Diplomatari, p. 88. El caso más conocido es la fijación de Termini Antiqui Civitatis Ilerde a partir de torres. La transferencia de la torre del mauro Picat como una entidad patrimonial integra se reflejaba en una donación efectuada antes de la conquista, que de ser auténtica evidenciaría un proyecto de traspasos de propiedades bien elaborado con anterioridad a la toma de Lleida, Diplomatari, pp. 107-108. Sobre las torres y su evolución véase, Bolòs, J.: «Paisatge i societat al Segrià al segle XIII» en Paisatge i societat a la Plana de Lleida a l'Edat Mitjana, Lleida, 1993, pp. 45-81/54; y ERITJA, X.: De l'almunia a la Turris: organització de l'espai a la regió de Lleida (segles XI-XIII), Lleida, 1998, quien a la función defensiva añade el valor simbólico de las torres, p. 19. Sin embargo, el autor omite una misión primordial de las torres en un terreno fundamentalmente llano, como fue la de control, dominio y sometimiento del territorio desde una posición en altura, útil en la supervisión de la producción agraria. Del pasado andalusí de las torres, se ha destacado sus nombres árabes, frecuentemente antropónimos, que para S. Bassols denominaban las personas encargadas de su defensa y he identificado con sus propietarios, siendo una expresión de la señorialización andalusí: «Una línea de torres vigía musulmanas: LleidaTortosa» en Al-Qantara, (Madrid) XI 1 (1990), pp. 127-154/ 153. 
Las actuaciones del conde de Urgell, Armengol VI, en la región cercana a Balaguer y especialmente en la del Mascançà, ponen de manifiesto las dificultades para extender su poder. Por esto, buscó la fidelidad de algunos señores, y mantuvo divergencias o conflictos con otros. En 1139, el conde «concedió» una torre en Almenara a Ramon Arnal, que este había edificado, otros beneficios, y en 1140 unas casas en Agramunt, para asegurarse su vinculación vasallática. Todo parece indicar que la dotación de un dominio que ya era del recipiendario respondía a la necesidad de reforzar o forzar la dependencia, máxime cuando había levantado una torre. Por esto, el conde legitimaba su acción argumentando que las tierras donde la había construido fueron otorgadas por sus antepasados, y para alcanzar su aquiescencia le benefició con más bienes. No obstante, en la misma fecha, Ramon Arnal había infeudado un alodio en el kastro de Almenara para que se hiciese staticam y, por tanto, se manifestaba ocupado en fortificar o en contar con vasallos en sus dominios al margen de la vinculación con el poder condal, como tantos otros señores de la zona ${ }^{17}$.

La importancia y autonomía de los señores explican que el conde de Urgell renunciase a la construcción de fortificaciones en el ámbito del collado de Negra en 1132, e incluso se comprometió a desmontar la que había edificado en Mania, aunque fue compensado con 200 sueldos de Jaca por los señores del sitio $^{18}$. Esto contrasta significativamente con las medidas de control e intervención en las fortificaciones que desarrolló Ramón Berenguer IV.

En el proceso de fijación de relaciones de vasallaje de la comarca, se manifestaron otras discordias o conflictos, y significativamente con el conde de Urgell. En 1138 Arnau de Ponts y sus hermanos infeudaron Bellester con consignas de construir una fortificación. Concedieron al antedicho Ramon Arnal la mitad del beneficio, del diezmo, del censo agrario o de los usos, y a dos vasallos la otra mitad, aunque sin participación en las rentas, salvo las primicias sujetas a la decisión señorial. La diferenciación del trato entre los vasallos de Bellester respondía a la posición destacada de Ramon Arnal en la jerarquía regional, por lo que adquiría unas mejores condiciones, aunque al parecer, y quizás por ello, generó problemas a sus señores. En 1143, Arnau de Ponts le instaba a retener

17 Diplomatari, pp. 90 y 89 respectivamente para Almenara, y el «donativo» condal de las casas de Agramunt o de los derechos en la percepción del diezmo si se implicaba en las mejoras del término, Codoin, IV, p. 66; y otras donaciones de Armengol VI a Ramon Arnal de torres en lugares próximos como Almazor, o las de Afif y Cendrosa, FOnT RIUS, J.M., Cartas, II, p. 102. La vinculación del lugar de Almenara a la casa condal de Urgell se documenta en 1063 o 1133 , Diplomatari, pp. 35-6 o pp. 83-4. Aunque se ha destacado que el conde quería sujetar a Ramon Arnal, o incluso se aprecia cierta actuación «independiente» del mencionado Ramon en Almenara, éste salía bien parado con los bienes que renovaban la vinculación. Otras actuaciones del conde, Armengol VI, perseguían consolidar la fidelidad de vasallos en la zona, como en la donación de la torre destruida Faneca, donde renunciaba a las rentas a cambio de la exclusiva del vasallaje, y nuevamente justificaba la donación-vinculación con una anterior concesión de Armengol IV al padre del beneficiario que se había hecho antes de la caída de Balaguer, Diplomatari, p. 97 (1143).

${ }_{18}$ Diplomatari, p. 81: ...Et ipsa fortitudine qui est facta in Mania desfaciam sine engan. 
sólo dos yugadas dando el resto ad homines que ibi maneant y para incentivar la construcción de la fortaleza les eximía de cualquier servicio - ost nesque cavalcata, nec iova nec tragi_. Siguiendo la fórmula de las «conveniencias», Ramon Arnal se comprometía a construir la mitad de la torre y la albacara como hacían los otros beneficiarios.

Arnau Ponts procuraba un mayor reparto de tenencias para consolidar la población, quizás acabando con un acopio o mal reparto por parte de R. Arnal, y de esta forma podía disponer de más gente implicada en las obras de la fortificación, que no se habían acabado según lo previsto en 1138. Por tanto, se intentaba asegurar el poblamiento y la defensa del lugar, pese a que teóricamente quedaban exonerados de prestaciones militares de ataque. La descripción de los «servicios» es elocuente de la mentalidad señorial que asimilaba dos formas de prestaciones correspondientes a distintas dependencias, pues identificaba los servicios militares vasalláticos y las corveas campesinas ${ }^{19}$.

Posteriormente en 1147, el conde de Urgell libraba el castillo de Bellester a Arnau de Ponts, y, según aclaraba, lo hacía al fin de un contencioso ${ }^{20}$. Esta referencia, las exigencias de fortificar y la iniciativa de involucrar como vasallo al destacado Ramon Arnal demuestran las divergencias entre la feudalización dirigida por los señores y las tentativas de consolidación del poder condal en la región. Las «donaciones» de Almenara o Bellester efectuadas por Armengol VI de Urgell no fueron concesiones en un sentido estricto, sino que formalizaban o imponían la dependencia de dos miembros principales de la aristocracia local precisamente en un contexto excepcional marcado por la proximidad de la expansión. En otros ámbitos de la Cataluña Nueva, las actuaciones de Ramón Berenguer IV también se produjeron a remolque o en contra de las iniciativas de señores del territorio, como en la Conca de Barbera, en el Camp de Tarragona, y, en menor medida, en las regiones feudalizadas bajo su dirección y la del conde de Urgell. Con todo, en la segunda mitad del siglo XII, las iniciativas condales y del rey Alfonso el Casto reactivaron su dominio sobre estos ámbitos que habían sido las fronteras de los condados.

Las regiones de las Marcas — la Conca de Barberà, la Baixa Segarra, las Garrigues - sufrieron un proceso de reordenación de la aristocracia feudal condicionado por la expansión, en el que se fortalecieron señores destacados en detrimento de otros, no sin controversia e incluso con conflictos armados. Desde los años treinta, se establecieron nuevas relaciones de dependencia vasallática

19 Cartas, p. 94 - fechado en el 1139- y Diplomatari, pp. 88-89; y el segundo documento en pp. 97-98. Uno de los hermanos de Arnau de Ponts obtendría la torre de Bellcaire, y al igual que otros elementos destacados de la clase feudal regional era a su vez señor y vasallo. La exención de obligaciones a cuenta de los trabajos de fortificación se produjo en la Cataluña Vieja, Cardona (986) o Ribas (990), Cartas, pp. 14-18 y 19-20. La equiparación de los servicios no significa que se exigiesen a todos los dependientes.

${ }^{20}$ Diplomatari, p. 105, le concedía como alaud, y con todas las rentas que refleja el reconocimiento del pleno dominio, aunque debía responder al abandono de posibles reclamaciones como señor. 
en un contexto complejo marcado por derechos antiguos, pugnas, la intervención de los condes o la introducción de las órdenes. En los cincuenta, algunos señores se afianzaron en distritos castrales de la Conca o de las Garrigues e intensificaron la concesión de beneficios para disponer de vasallos in situ. Estas iniciativas respondían a la culminación de la conquista de Lleida pocos meses atrás, como las llevadas a cabo por la familia Cervera en Espluga según ha analizado A. Altisent ${ }^{21}$. Las nuevas condiciones de seguridad alentaron el fenómeno colonizador, si bien los espacios conquistados se comportaron asimismo como horizontes para la emigración y una clara competencia para los ámbitos feudalizados o en vías de feudalización.

En un contexto parecido, en Tarragona se adoptaron medidas para atraer y estabilizar a la población en los preámbulos y tras la conquista de Tortosa. Antes de la contienda, se legisló para evitar el acopio de tierras en pocas manos, que podía limitar la presencia e intereses de los caballeros establecidos o venideros. Después de la toma de Tortosa, se ofrecieron situaciones atractivas para los pobladores. En los años siguientes, los señores intensificaron la feudalización de los distritos castrales del territorio tarraconense mediante la fijación de vínculos vasalláticos ${ }^{22}$.

En definitiva, los señores de los ámbitos de Tarragona, de la Conca y de las Garrigues consolidaron su poder y recursos a través de la fijación de dependencias vasalláticas, y procuraron arraigar el poblamiento en un momento de cambio fundamental. Además algunas intervenciones señoriales posiblemente perseguían conseguir una posición privilegiada ante la eventual conquista de las tierras vecinas andalusíes, como parece sucedió con los Cervera en Espluga y cuya participación en la empresa de Siurana lo confirma ${ }^{23}$.

A. Altisent observó certeramente que el linaje desarrolló «un plan de colonización bastante completo», e incluso se puede plantear la hipótesis que acaso programó la feudalización de una amplia región desde Espluga, para asegurarse un papel preeminente en la zona más allá de los límites locales. Con ello, los Cervera afianzaban el dominio del territorio contiguo al reino de Siurana poco antes de su conquista, lo que les facilitaría el control del distrito musulmán una vez ocupado. Esto explica que sus dos primeras donaciones de 1150 afectasen a

${ }^{21}$ Las actuaciones del linaje son conocidas gracias al minucioso y completo estudio de Altisent, A.: «Un poble de la Catalunya Nova els segles XI i XII. L'Espluga del Francolí de 1079 a 1200» en Anuario de Estudios Medievales, o AEM (Barcelona) 3 (1966), pp. 131-216/ 143. Esta comarca estaba bajo la dominación feudal desde hacia más de un siglo; y por tanto las actividades de los Cervera no surgían ex nibilo ni eran colonizadoras en un sentido estricto.

${ }^{22}$ Los análisis y detalles según BONET, M.: «La feudalització de Tarragona (segle XII)» en Butlletí Arqueologic, (Tarragona) V 16 (1994), pp. 211-239/ 218-221.

23 El horizonte de la conquista de Siurana se expresa en una donación hecha por Ponç de Cervera a Guerau de Segura, cuando le imponía que fijase su residencia en Espluga ...cuando siat de cristianos Ciurana..., o el vasallo Guerau se comprometía explícitamente a defender el lugar con los suyos en caso de que hubiese «guerra» en el chastrum d'Espluga, Diplomatari, pp. 123-4, (1151). La participación de Ponç y Ramon Cervera en Siurana, MORERA, E., op. cit., pp. 428-429. 
términos castrales en un perímetro extenso —Conesa, Tallat, Espluga_, y a capellanías en lugares bien alejados entre si -Espluga, Tallat, Passanant, Albarca-. Las posiciones más bien extremas respecto del «núcleo central de Espluga» muestra como la mencionada familia trataba de asegurar su presencia en los límites donde ejercía o proyectaría su poder ${ }^{24}$. Además la concesión de las capellanías al eclesiástico Pere de Pinós revela su voluntad de tener un dominio total, inclusive de la jurisdicción eclesiástica y seguramente en algún lugar de lo que aún era el valiato de Siurana, como se desprende de la adjudicación de Albarca al otro lado de la sierra, enfrente de Siurana. En este contexto, la donación de Poblet al Císter efectuada por Ramón Berenguer IV posiblemente en 1151 se revelaba ajena o disconforme al despliegue de los Cervera, y quizás a la circunstancia que afectaba al dominio eclesiástico ${ }^{25}$.

Además de las antedichas concesiones de envergadura, los Cervera se encargaron de dotar a otros vasallos con bienes más modestos, fijando condiciones distintas y más favorables a los beneficiarios importantes, como también se ha visto que sucedió en Bellester. En la infeudación de una cuadra en Espluga al poderoso Ramon Boixadors, se le dio todo el diezmo en tanto que habitualmente Ramon o Ponç de Cervera retuvieron la cuarta parte o la mitad del diezmo. Además, el trato de favor a R. Boixador se justificaba por la ayuda en la defensa de Espluga o a cambio de que hiciese casas en el castillo, siendo manifiesto el interés del señor por alcanzar su fidelidad y concurso ${ }^{26}$.

24 Pere de Queralt beneficiario de la donación de los castra, tendría vasallos en Conesa y el Tallat, y pese a que Ramon de Cervera se reservaba estratégicamente un baiulo en Espluga, él podría tener cinco caballeros allí, Diplomatari, pp. 116-117 (1150), y pp. 120-1 respectivamente. La existencia de lazos anteriores, que entraban en colisión con los derechos fijados con esta nueva relación feudovasallática, se plasma en el «incongruente» juramento ligio hacia el nuevo señor - Ramón de Cervera-, que hizo Pere de Queralt, puesto que aclaraba que hacía una excepción con la vinculación a su señor de Queralt, y a quien se comprometía servir en caso de que ambos señores mantuvieran un conflicto, ofreciendo a algún pariente como substituto suyo en las obligaciones hacia el Cervera. Además estos dominios estaban ya infeudados, como el Tallat concedido por R. de Cervera a Guillem de Cabrera sólo tres años antes, o Conesa veinte años antes y en la que no aparecía el linaje de los Cervera.

${ }^{25}$ La primera donación de Poblet data de 1150 pero parece que es una falsificación, y que debía perseguir anteceder en una semana a las mencionadas intervenciones de los Cervera o bien a la fundación de Valldaura - Santes Creus- de fines de 1150. Por este asunto, el monasterio de Poblet mantuvo un pleito en la época moderna para determinar cual de los dos era el primer cenobio cisterciense catalán. De la posible falsificación extraña la confirmación de Ramon de Cervera, quien daba la mitad del huerto de Poblet al Císter, sin mención a los límites, —a sólo dos kilómetros de Espluga-; a la que no aludiría después, y que era contradictoria con la donación de la capellanía de Espluga a Pere de Pinós. La segunda donación al cenobio cisterciense del 18-VIII1151, ya fijaba un término concreto, y aún si parece auténtica, no tuvo consecuencias hasta 1153 , Diplomatari, pp. 115 y 127 respectivamente. A propósito de su veracidad, parece significativo el hecho que Ramón Berenguer IV se llamase príncipe de Tarragona, categoría que asumía en el mes de agosto, y sólo se intitularía ocasionalmente así hasta el mes de noviembre, que confirma la propuesta de A. Altisent de 1151 como única fecha posible para el segundo documento.

${ }^{26}$ Diplomatari, p. 122; la cuadra implicaba dependencia vasallática y solía ser una parte del espacio castral, SABATÉ, F.: El territori de la Catalunya medieval, Barcelona, 1997, pp. 94-5. 
En otros donativos se involucraba a los beneficiarios en la defensa y residencia en el lugar, como en el de Salavert a Berenguer de Sentdomí en $1150^{27}$. Asimismo, Ramon de Cervera reclamó a Pere de Malacara el auxilium en caso que gerram habuerimus de ipso kastel d'Espluga, en una cesión de $1153^{28}$. Una referencia tan explícita, y a su vez inusual, apunta a un conflicto en ciernes, que podía ser la conquista de Siurana, o la manifestación de una crisis como resultado de la «recomposición» del estamento señorial en la «retaguardia», que justificaría una advertencia igual en $1159^{29}$. En definitiva, el principal linaje del lugar confirmó o trabó alianzas mediante la concesión de beneficios, con el propósito de consolidar la feudalización bajo su autoridad.

Sin embargo, y pese al despliegue desarrollado desde la Espluga, los Cervera no fueron los únicos agentes de la reorganización feudal en la región, y otros señores importantes o el conde de Barcelona actuaron en estas fechas en lugares cercanos de forma aparentemente complementaria, aunque no por ello exenta de competencia. La donación de Ramón Berenguer IV de Tarrés a Ramon Boixadors en 1149 dio paso a otras concesiones efectuadas por el beneficiario, cuyos confines eran cercanos a las realizadas por sus amigos de la familia Cervera y compartían la voluntad de dirigir la feudalización en sus respectivos distritos. Además la carta condal contrasta con las libradas por el Boixadors, ya que el conde nada retenía, quizás porque su objetivo fundamental era consolidar su jurisdicción, más teórica que otra cosa y legitimar los límites del término. En este sentido, cabe explicar que antes de 1149, la actividad de R. Boixadors en Tarrés era independiente, e incluso el reconocimiento de la procedencia condal del patrimonio en 1126 se desdibujaba al añadir y aclarar et per ullasque voces, y en 1149 todavía mantenía cierta dualidad respecto del origen del dominio per donacionem Raimundi comes...sive per aprisione $e^{30}$.

En 1151 Ramón Boixadors definió la feudalización de Tarrés mediante la dotación de cuadras a vasallos, exigiéndoles su vinculación en la defensa, y la mitad del diezmo. Más tarde, en 1156, infeudó todo el término castral y Fulleda, reteniendo su participación en un mayor número de derechos señoriales. Este pacto se acomodaba a una nueva realidad, en la que el señor ya no estaba

${ }_{27}$ Altisent, A.: op. cit., p. 135 o en la donación a Arbert y Saurina de una caballería considerada ...inter feu et alod, cuya disyuntiva muestra la flexibilidad de los conceptos jurídicos (1150), Diplomatari, p. 121. En la concesión de propiedades en la Espluga a Bernat Rovira no se especificaban las obligaciones militares ni la retención de dominio del Cervera, aunque Bernat se comprometía a serle «sólido», Cartas, pp. 136-7 (1151).

${ }_{28}$ Diplomatari, p. 137.

29 Diplomatari, p. 175; y el análisis del progreso feudalizador, ALTiSENT, A.: op. cit., pp. 146-7.

30 Diplomatari, pp. 72-73, 111 y 125, respectivamente. En otras ocasiones, los señores manifestaban el origen doble de su patrimonio, condal u de otras fuentes, como en los de Bellester, de Montmur o de Penelles d'Algareix — concedidos por el conde de Urgell—, y aunque la fórmula no es excepcional tampoco parece una mera expresión retórica. Sobre los Boixadors véase, ALtisent, A.: ibidem, pp. 183-188. 
preocupado por la fortificación o defensa de las cuadras y en cambio, precisaba las prestaciones económicas que obtendría o la presencia de sus representantes en el lugar —un eclesiástico, un batlle, y un herrero- - R. Boixadors se reservó la mitad de los habituales diezmos y estacamentos, de las exorquias o cugucias - malos usos_-; o de derechos arbitrarios como las chestias y trobes, et de toltes et de forces que exeant per amore vel per forca, así como cargas en trabajo, tragins... ioves $^{31}$. Esta relación de rentas se aproximaba más a la realidad de las prestaciones percibidas que la reseñada en las retenciones dominicales de la comarca, que a menudo se ceñían a diezmos y otros ingresos jurisdiccionales. Sin embargo, el diezmo —o la décima - mantenía el carácter singular entre las rentas de Tarrés, lo que confirma la atribución de un valor distinto o relevante, como podía ser el reconocimiento de señorío, aunque desde estas fechas emprendería un nuevo rumbo ligado a la vinculación a la jurisdicción eclesiástica.

La primera intervención del conde de Barcelona en la zona se produjo durante el asedio de Tortosa — 1148_, cuando concedió a Porcel de Cervera, su batlle y a otros Espluga Calba, reteniéndose la novena de la producción agraria $^{32}$. Su posición occidental y adelantada hacia Lleida la situaba como una avanzadilla más para alcanzar la urbe. El objetivo era, de nuevo, asegurar el poblamiento, pero la modalidad documental escogida era ya una carta de población. Sin embargo, otras acciones de Ramón Berenguer IV en la zona, como la concesión de otros instrumentos poblacionales en las inmediaciones de los dominios de los Cervera o de los Boixadors, o la trascendente donación de Poblet se explican como reacción a las intervenciones de estos señores ${ }^{33}$. Asimismo, el conde barcelonés consolidó su presencia en los contornos del valiato de Siurana con el fin de llevar a cabo o monopolizar la conquista, lo que indirectamente explica la cesión de los pastos de las montañas de Prades — montana Ciurana - a los pobladores de Vinaixa en 1151 o su explotación a los habitantes de Vimbodí - limítrofe con Espluga_, y en ambas cartas de población se reservaba la novena ${ }^{34}$.

La fórmula poblacional fue fundamental en las actuaciones señoriales en décadas sucesivas y contribuyó al alumbramiento o la consolidación de las oligarquías locales, socialmente más heterogéneas. Después de las conquistas de

${ }^{31}$ Diplomatari, p. 159. El beneficiario infeudó la cuadra de Fulleda según un pacto tripartito, ibidem, p. 167.

32 Cartas, p. 109.

33 Vale la pena recordar que Ramón Berenguer IV se había enemistado con Ponç de Cervera cuando secuestró y se casó con su hermana Almodís, aunque se reconciliaron por su participación en las empresas de conquista.

${ }^{34}$ La donación de Vinaixa se destinaba a los habitantes procedentes de Tàrrega, mientras en Vimbodí los pobladores ya estaban, y muestra como en la primera se impulsaba la población en tanto que la otra confirmaba un sitio poblado, Cartas, pp. 138-9 y 140-1. Sin embargo, en el refrendo de la carta de población de Vinaixa del 1152 se omitía el derecho de aprovechamiento del bosque, Cartas, pp. 142-3. 
Lleida y Siurana, los condes optaron fundamentalmente por la donación de cartas de población en las Marcas, aunque también efectuasen infeudaciones como la de Tarrés. En las décadas de los cincuenta y sesenta, el conde de Urgell, Armengol VII, impulsó su concesión, en las que primaba la definición del canon por la explotación agraria — censu - y la afirmación de las dependencias personales respecto de su persona, lo que significaba un cambio en relación a las actuaciones de su padre orientadas a disponer de vasallos en espacios fortificados antes de la expansión ${ }^{35}$.

Las cartas de población guardaban relación con las de infeudación o las convenientiae puesto que en ambas se perseguía consolidar la población, si bien las primeras tenían como objeto organizar la explotación agraria, o incluso el reparto de tierras como en Espluga Calba y, en cambio, no se mencionaba ninguna obligación militar o de fortificación presentes en las infeudaciones de la región hasta entonces ${ }^{36}$. La concesión dirigida a varias personas o a todos los pobladores de los instrumentos poblacionales reforzaba el lugar principal del señor y rompía con la tendencia «jeraquizadora» derivada del sistema de dotaciones a título individual, de los tripartitos, de las subinfeudaciones o incluso de las infeudaciones colectivas. Además, la dependencia exclusiva de los destinatarios al otorgante de las cartas contribuía al fortalecimiento del poder señorial —el conde en los casos vistos-, puesto que eludía cualquier otra jurisdicción que a menudo era compartida en la dotación de feudo ${ }^{37}$.

Con todo, la vinculación personal con el concedente y la referencia a las prestaciones económicas a satisfacer por los beneficiarios fueron denominadores comunes de los pactos feudovasalláticos y las cartas de población. Sin embargo,

35 Tanto en la dotación de un alodio en Bellcaire (1157) como en la donación de Menàrguens a sus pobladores (1163) se fijaba un censo agrario en especie, con mención a la dependencia exclusiva con el conde de Urgell, Cartas, pp. 159 y 179-180 respectivamente. Esta iniciativa se inscribe en una serie de actuaciones poblacionales que afianzaban las localidades más importantes del condado —Agramunt (1163), Balaguer (1174)—, BERTRAN, P.: Bellcaire d'Urgell. Perfil històric, Bellcaire, 1982, p. 33.

${ }^{36}$ La cercanía de aspectos de las cartas de población respecto de los pactos feudovasalláticos se plasma en los préstamos del lenguaje, y el conde indicaba et convenio vobis, o in tali pacto en las cartas de Vinaixa, Vimbodí o in tali convenio en la de Espluga Calba. De hecho los beneficiarios eran a menudo personas destacadas de la comunidad local que actuaban como intermediarios entre los señores y otros elementos del campesinado como los de la carta de Espluga Calba, y sobre quienes se precisó quantum vos poteritis laborare et populare et illos alios pro vobis ibi fuerint populatos.... Además se constata que sus recipiendarios constituían la elite local, puesto que el primero era batlle del rey, y fue señor de otros ámbitos, y Miró de Fluvià, debía ayudar a mantener una propiedad, quizás como campesino, mediador, o poder local, Diplomatari, pp. 259-60 (1168).

${ }^{37}$ J.M. Font Rius destaca que la previsión de monopolio judicial, o de vinculación exclusiva al conde de Espluga Calba tendría una continuidad relevante —non..respondeatis ad ullum hominem-, op. cit., II, p. 194. En la de Vinaixa se expresaba la dependencia al concedente, el conde, ...salva mea fidelitate y la exclusiva señorial et convenio vobis ...non ponam alium seniorem preter me ipsum..., o en la de Vimbodí ...et non eligatis nec aclametis alium seniorem.... 
el señor exigía la totalidad de las rentas requeridas en los instrumentos poblacionales como la novena condal, mientras que se las repartía en los convenios feudovasalláticos con los vasallos y, aunque ello no implicaba necesariamente una tasa de sustracción mayor en los primeros, sí que respondía al progreso del poder señorial frente a los beneficiarios. De todas formas, las reclamaciones de rentas comportaban el reconocimiento de la dependencia económica o del señorío en sendas fórmulas documentales, y a ellas los productores agregaban otras cargas, que a veces se reflejaban en otras fuentes ${ }^{38}$.

El impacto de la gran expansión explica las transformaciones visibles en las intervenciones condales, y en actuaciones señoriales que contribuyeron a otra redefinición de las relaciones sociales. Así los señores de la vanguardia de las Marcas, poderosos y activos antes de las conquistas, perdieron el protagonismo e incluso parte de los dominios en pocas décadas, lo que explica las referencias a guerras, como en Espluga en los años cincuentas y otros episodios violentos en la comarca. Estas manifestaciones de conflictos feudales resultaban de la nueva definición de los poderes y dependencias que se produjeron a partir de la actividad de conde en la región y de las expansiones patrimoniales de Poblet, y del Temple desde Barberà posteriormente.

El monasterio de Poblet había sido una fundación estratégica de Ramón Berenguer IV, que se consolidó gracias a su protección o la de su hijo, y fue una pieza fundamental de la política condal orientada a alcanzar la imposición — o introducción efectiva_ - de su potestad en esta región y como contrapeso a los poderes señoriales, que habían dominado de forma prácticamente exclusiva el territorio. Las agresiones hacia los bienes y actividades de los monjes fueron condenadas y perseguidas por Ramón Berenguer IV, quien argumentó que un ataque a Poblet equivalía a una agresión a su patrimonio — $1160 \_$. Esta identificación de los bienes, aunque retórica, permitiría comprender la generosa concesión del derecho de pastos al monasterio en las tierras del conde ${ }^{39}$.

${ }^{38}$ La única renta prevista en el documento poblacional de Vimbodí era la novena, y luego en 1163 se había añadido el diezmo también para el rey, mostrando el carácter sesgado, teórico y benefactor de las cartas de población, Diplomatari, p. 197. En otros estudios he demostrado el valor parcial de la información en los instrumentos poblacionales a la hora de conocer el alcance de la renta feudal. También en las infeudaciones destacaban las retenciones de rentas judiciales y el diezmo según se ha visto, que no eran todas las reclamadas por el señor como se constata en Tarrés, donde además él hacía una referencia llamativa a las rentas arbitrarias, que se obtenían por amor o por la fuerza. No obstante, en otras fuentes documentales tampoco se ofrece la relación completa de las rentas, sino sólo aquellas significativas o alusivas a la dependencia respecto del señor - territorial o jurisdiccional- Así sucede en el Becerro de las Behetrías, donde no se mencionaban todas las percibidas por los señores, sino sólo las más indicativas del reconocimiento de señorío como analiza Álvarez BORGE, I.: «Los señoríos en Castilla la Vieja a mediados del siglo XIV» en Studia historica, (Salamanca) XIV (1996), pp. 181-220/ 183.

39 Diplomatari, p. 179 y Altisent, A.: Història de Poblet, Poblet, 1974, pp. 33 y ss. La economía de Poblet sobrepasó de forma espectacular el modelo de gestión de los dominios de la comarca de la Conca, que en general eran reducidos y sus beneficios se fraccionaban, mientras que el 
Otros episodios violentos se produjeron en contra de la expansión patrimonial del cenobio, como el ataque a los monjes que labraban la partida del Codoç en 1178, que antes era del señorío de la Espluga, y el rey la había unido a Vimbodí cuando libró este dominio a Poblet. De forma significativa, los señores de la Espluga Sobirana, Ponç de Cervera y Ramon de Torroja y algunos campesinos protagonizaron este enfrentamiento con los monjes. Su resistencia y un proceso alargado en el tiempo reflejan la capacidad efectiva de su oposición, aunque al fin se impuso el dominio del monasterio y Ponç tuvo que vender su parte del señorío a Ramon de Torroja en 1182, quien había marchado a Tierra Santa en el período más crítico del conflicto originado por el Codoç, quizás esquivando el problema como sugiere A. Altisent ${ }^{40}$. La aristocracia de la región que había consolidado dominios y posiciones a mediados del XII, o bien se integró directa o indirectamente en el monasterio como Pere de Queralt haciéndose monje, y Ramón de Cervera procurando importantes donativos, o bien perdió su poder hasta «desaparecer» como su hermano y sobre todo su sobrino ambos de nombre Ponç ${ }^{41}$.

La resistencia de otro señor de la comarca, Pere de Puigvert, a las actuaciones de Ramón Berenguer IV contrarias a sus intereses terminó en un juicio en 1157, donde se debatió la titularidad de los castillos de Prenafeta, Piera, y Barberà. El proceso reflejaba episodios de violencia perpetrados por Pere en caminos y a mercaderes, que el conde consideraba un ataque a su persona ${ }^{42}$. Su dominio en Barberà había sido objeto de donativo a los templarios por el conde de Urgell y el de Barcelona (1132/35) y, pese al pleito, el cambio de señorío se demoró hasta los años setenta con la formación de la encomienda. Al igual que en Poblet, la nueva situación liquidó derechos señoriales y contribuyó a la transformación de la sociedad que ya no vivía en la frontera.

También se dieron situaciones conflictivas cuando el monasterio cisterciense de Valldaura se trasladó a Santes Creus en 1160 y laminó antiguos derechos dominicales o de la población. Sirva como ejemplo la resistencia del señor y los campesinos de Cabra al crecimiento del cenobio, que se zanjó con la renuncia del primero, Guillem de Pontills, en 1187 y con una «concordia» que recordaba o imponía la dependencia territorial y jurisdiccional a los hombres de Cabra en 1188. Aunque se les reconocía sus derechos como tenientes de las tierras, se les impuso una nueva renta, la tasca, con el fin de redimir los perjuicios come-

cenobio alcanzó un patrimonio importantísimo y una extraordinaria expansión ganadera, consolidada con este y otros privilegios de la monarquía. La identificación de la monarquía con el cenobio alcanzó su máxima expresión cuando el rey Alfonso lo escogió como lugar de sepultura en 1176.

${ }^{40}$ Altisent, A.: Història..., p. 56 y Un poble..., pp. 165-68. La situación conflictiva explicaría el consentimiento del conde para que el monasterio pudiese admitir a caballeros o peones.

${ }^{41}$ Diplomatari, pp. 330-331 — testamento de Ramon de Cervera-, p. 334 —renuncia de su mujer-, pp. 402-3 —otros donativos—y p. 225 — derecho de explotación de piedra en su dominio-.

${ }^{42}$ Codoin, IV, pp. 255-260. Pese a la oposición a perder sus derechos, más tarde legó al Cister y al Temple parte de su patrimonio, Diplomatari, p. 238 (1165). 
tidos al monasterio. Así se introducía un censo con el que se definía una nueva situación de sometimiento y se castigaba la oposición ${ }^{43}$.

En definitiva, la aristocracia que había intensificado su consolidación en los tiempos previos a la gran expansión dejó su «vocación» militar en un segundo plano y perdió cierta hegemonía territorial compartida ante nuevas formas de organización social o gubernativas que consolidaban a los señores y a las oligarquías locales emergentes. Se fijaron nuevas dependencias personales, como en Cabra o las impuestas en una sentencia de 1187 a los habitantes de Espluga que habían roturado las tierras del Codoç, y pese a ello debían labrarlas ad servitium Populeti y pagar la novena. Además se declaraba el cambio de dependencia detallándose la pérdida de dominio de los señores de Espluga y se rubricaba otra vez con nuevas exigencias económicas a los payeses.

\subsection{La afirmación de los grandes señores en los territorios de Tarra- gona y Siurana}

En la feudalización de los territorios de Tarragona y Siurana se introdujeron nuevas fórmulas de dependencia personales o económicas, que se distanciaron de las que caracterizaban el proceso en las Marcas, si bien las modalidades contractuales eran próximas. Los grandes señores, el arzobispo, su vasallo y el conde de Barcelona, dirigieron el fenómeno de implantación señorial, aunque en la década de los cincuenta entraron en conflicto por el liderazgo en la cúspide del dominio tarraconense. Precisamente en las mismas fechas Ramón Berenguer IV organizó el reparto feudal del territorio de Siurana siguiendo los mecanismos desarrollados desde Tarragona, que en ambos casos reforzaban la posición primordial del señor eminente. La imposición del conde como figura preeminente en el ámbito de Siurana contrasta con su papel rector en la implantación del sistema feudal en las regiones de Tortosa y Lleida, donde llevó a cabo políticas más complejas y participadas, que respondían a la necesidad de sometimiento de poblaciones urbanas andalusíes. De todas formas y, a pesar de las diferencias entre sus actuaciones, las acciones condales en todas estas regiones adquirían una especificidad distinta y distante a las típicas de un señor.

La feudalización de la ciudad de Tarragona, y de su amplio territorio, el Camp de Tarragona, se emprendió en la década de los treinta, intensificándose a raíz de las conquistas de mediados del siglo XII. A diferencia del resto de ciudades de la Cataluña Nueva, esta había padecido un fenómeno de discontinuidad y abandono poblacional en una zona que estuvo al margen de los poderes musulmanes y cristianos circundantes durante más de un siglo. En 1129 el arzobispo y señor de Tarragona, infeudó la ciudad y el territorio al caballero normando Robert Bordet, y le nombró príncipe, quien enseguida concedió

${ }_{43}$ LBSC, pp. 291-2, 294-5 y 313. 
feudos respondiendo el encargo de atraer población ${ }^{44}$. En la primera etapa de intervención de Robert, los beneficiarios de las convenientiae establecieron a otros vasallos, según sucedía también en las Marcas. Así se revela en las infeudaciones de Mangons en 1149, donde había un total de tres vasallos por debajo del normando, y los últimos retenían la tercera parte de las rentas, las dos terceras del molino y todas las stachamenta — de forma muy parecida a los tripartitos de la Conca de Barberà- ${ }^{45}$.

Este proceso conllevó tal conflictividad que dos décadas después fue necesario establecer dos árbitros o iudices para cometer el reparto de las tierras y se prohibieron las arbitrariedades señoriales con la significativa excepción hecha a los nuevos jueces ${ }^{46}$. Las dificultades entre los señores tuvieron su máxima expresión en la pugna entre el arzobispo y su vasallo, cruzándose acusaciones en una curia condal en 1151, como las vertidas por el prelado sobre los abusos cometidos por el hijo de Robert Bordet. Días después, el arzobispo libró el senioraticum de la ciudad y el territorio al conde de Barcelona y definió unos mejores términos como señor eminente, aunque los Bordet siguieron ejerciendo su poder al menos durante dos décadas más ${ }^{47}$.

Desde mediados del siglo XII, las nuevas condiciones surgidas tras la expansión meridional y el conflicto señorial ocasionaron un impulso feudalizador con directrices diferentes a las del primer período de ocupación que habían sido cercanas a las contemporáneas de las Marcas. Los grandes señores, Robert Bordet y sus sucesores, Ramón Berenguer IV o el arzobispo, fijaron nuevas dependencias con el fin de alcanzar el dominio en ámbitos del Camp de Tarragona y exigieron fortificar y «poblar» a los nuevos feudatarios. A partir de esta política orientada a concentrar la población, se definió la organización del poblamiento del Camp en base a una serie de núcleos destacados ${ }^{48}$. Además, se tejieron vinculaciones de dependencia entre los señores de las localidades y los de la ciudad, lo que contribuyó al desarrollo de la centralidad de la ciudad medieval en el ámbito feudalizado.

Ejemplos de esta segunda fase de la organización feudal son la concesión de la mitad de Riudoms hecha por Robert Bordet a Arnau Palomar en 1151, o la

${ }_{44}$ Cartas, pp. 87-89. Sin entrar en el complejo fenómeno de la restauración de Tarragona, cabe advertir que el pacto feudovasallático de 1129 se apartaba significativamente de las convenientiae de las Marcas, puesto que en él se diferenciaban las jurisdicciones, laica y eclesiástica, y la institución del príncipe se alejaba de la figura típica de vasallo. Tal consideración se reflejaba en la concesión de los derechos de tránsito de mercancías que le correspondían ...quae ad principem pertinent.... El título y los derechos vinculados a este remiten a la idea de poder "público» o de una autoridad distinta a la de un vasallo sin más, y aunque fuese una maniobra del arzobispado para desmarcarse del conde de Barcelona, se estaba introduciendo una innovación política trascendente.

${ }^{45}$ Cartas, pp.114-5 y el análisis de las infeudaciones en BONET, M.: op. cit., p. 219.

${ }^{46}$ Cartas, pp. 120-1 ...nullus hominum faciat districtum, vel aliquam fortiam seu exactionem nisi illi duo iudices...
${ }^{47}$ Codoin, IV, pp. 187-192.
48 BONET, M.: op. cit., p. 228. 
de Cambrils, efectuada por Ramón Berenguer IV a Pons de Regumir en 1152, en ambos casos para su fortificación y con la retención dominical de la mitad. Luego, en 1155, el conde de Barcelona impulsó la población de su mitad de Cambrils, concediendo casas o tierras a los habitantes y reservándose los diezmos, las primicias, la justicia, la fidelidad y los hornos ${ }^{49}$. En ocasiones, sendas intervenciones señoriales colisionaron en un mismo lugar, como en Cambrils, que, asimismo fue concedido por Robert Bordet a Bertrà de Cambrils. La tentativa de substitución de Robert Bordet por el conde no prosperó según lo previsto, y durante los años cincuenta el normando o su familia no cejaron en la actividad de dotación de feudos de sitios como la Boella, Salou, Vilafortuny o Burgà ${ }^{50}$.

Del mismo modo, el arzobispo realizó nuevas infeudaciones, como la de Reus con el fin de estimular la población (1154), y a veces de acuerdo con su nuevo vasallo, como en la de Raurell o de Barenys, cuyo beneficiario quedaba comprometido a prestar servicio de armas al arzobispo y se le exigía residencia en Tarragona ${ }^{51}$. La especificación de las obligaciones militares, la exigencia de fortificación, o la disponibilidad de vasallos en el territorio respondían a la necesidad de los grandes señores de garantizar fidelidades en el Camp de Tarragona. Esto presagiaba la época de máxima hostilidad entre ellos en la década de los sesenta, que estuvo marcada por una guerra de bandos entre el arzobispo y su primer vasallo. Sin embargo, el conflicto no frenó la actividad feudalizadora, y se repitieron las donaciones de un mismo beneficio por parte de los principales confrontados, que sólo se zanjó con los asesinatos de Guillem Bordet por instigación del arzobispo (1168) y del mismo prelado por el hermano vengador de Guillem $(1171)^{52}$. Luego el rey remplazó casi definitivamente a los Bordet como vasallos del arzobispo, en tanto que este afianzó su posición dominante en la cúspide señorial tarraconense.

Las actuaciones de los señores de la ciudad buscaron consolidar las fidelidades de otros secundarios del Camp de Tarragona, aunque manteniendo cierto control del lugar o su presencia en el territorio, mediante la reserva de una parte del dominio o de algunas rentas de forma exclusiva. Por tanto, el papel de los grandes señores de Tarragona fue muy importante y trascendente en la feudalización de la región, sobre todo si se compara con el de sus coetáneos de las Marcas. Además, algunos pocos vasallos se convirtieron en destacados lide-

49 Por cuanto atañe a Riudoms, Cartas, 135-6; y a Cambrils, Cartas, pp. 143-4 y 150-1 respectivamente.

${ }^{50}$ Cartas, pp. 132-3 — Boella-; Salou presenta una primera infeudación en 1152, con mención a fortificar y a concentrar la población según el modelo citado y otra diferente de 1157 , MORERA, E.: op. cit., p. 445; para Vilafortuny resulta revelador el juramento de fidelidad de su señor Guillem Fortuny a Ramón Berenguer IV, aunque precisaba que se debía al arzobispo y a Robert Bordet, Codoin, IV, pp. 224-5, (1154); para Burgà, Cartas, p. 157.

${ }^{51}$ Bertrà de Castellet obtuvo dos partes de la localidad o dominio de Reus y el arzobispo se reservó la iglesia, BlANCH, J.: Arxiepiscopologi, I, Tarragona, 1985, p. 89 y p. 93 - Barenys-.

52 MORERA, E.: op. cit., pp. 462 y ss.; BONET, M.: op. cit., pp. 232-6. 
res que proyectaban sus intereses en ámbitos amplios, más allá del feudo obtenido, contagiados del modelo que fortalecía a los más importantes, y de forma complementaria con éste.

Algunos testimonios del progreso de la nueva aristocracia feudataria se encuentran en personajes como Bertrà de Castellet, quien señoreó desde Siurana sus inmediaciones y obtuvo Reus; o Bertrà de Cambrils, quien beneficiario de Cambrils, intervino en la feudalización de Alforja o amplió derechos hacia el ámbito de Riudecanyes, y el poderoso Guillem de Claramunt, señor de Tamarit, fiel a sus señores, los Bordet. La tensísima situación en la cúspide señorial explicaría la coincidencia entre el desarrollo del poder de los señores y el de sus principales dependientes o aliados, en lugar de la manifestación de las lógicas contradicciones.

La posición de privilegio de los grandes vasallos de la zona, incluso de los establecidos por el linaje expulsado, explicaría que en 1185 el rey Alfonso concediese Cambrils a Bertrà de Cambrils, que había sido beneficiario de los Bordet. El monarca estaba plenamente asentado en el señorío tarraconense y, sin embargo, asumió el poder de quien seguramente había administrado el lugar durante tres décadas en contra de lo previsto por su padre, e incluso le amplió el dominio hacia el sector de Riudecanyes ${ }^{53}$.

La situación en el distrito de Siurana fue distinta ya que fue el conde Ramón Berenguer IV quien feudalizó el antiguo valiato andalusí tras su conquista -1153/54 - concediendo cartas de población o infeudaciones estratégicas. A la carta de población de Siurana, le sucedieron las infeudaciones de Albiol a Joan Martorell y Alforja a Ramon Gavalgand (1158), a quienes se les exigía que fortificasen y poblasen según sucedía en el Camp de Tarragona, y luego libró la carta de población de Prades $(1159)^{54}$. Al igual que en otros casos vistos, el conde utilizó las infeudaciones y las cartas con fines próximos y, de forma muy significativa, para la fijación de los vínculos de dependencia, aunque las fórmulas de delegación de las primeras eran substituidas por la exigencia de la vinculación al señor de las cartas, reflejando el cambio en la definición del poder señorial.

El derecho de conquista amparaba las actuaciones condales en Siurana, que afectaban a un territorio que anteriormente había sido vinculado al dominio de Tarragona, aunque de forma teórica y difusa. Por este motivo, el conde explicitaba en las infeudaciones que estaban en los terminos de Siurana, legitimando su

53 Cartas, pp. 242-3; nuevamente se imponía al vasallo el encargo de poblar y fortificar en un lugar ya ocupado, aunque con la «confirmación» el rey había ampliado su retención a tres cuartas partes de rentas jurisdiccionales y otras.

${ }^{54}$ Cartas, pp. 148-9; pp. 161-2; pp. 162-4; pp. 165-6. En las obligaciones de los vasallos se indicaba: ut facias (ibi) fortitudinem et populationem. En el instrumento poblacional de Siurana, pese a que se refiere a su caballero Bertrà de Castellet, quien ha procedido al reparto de casas y tierras, el conde les recuerda que son sus ...veri fidelis, sujetos a su jurisdicción, y al parecer Bertrà de Castellet quedó relegado a un plano discreto. 
acción por la toma del lugar. En todas sus actuaciones, ya fuese en las infeudaciones o en las cartas de población, Ramón Berenguer IV se reservó los diezmos y las primicias, como hizo en la carta de Cambrils. Esta reserva de rentas tenía la misma finalidad que la de la novena parte de la cosecha de alguna donación condal en la comarca vecina de la Conca de Barberà. La retención de prestaciones económicas en exclusiva era equivalente y significaba el reconocimiento de señorío en exclusiva, y la elección de rentas eclesiásticas en un territorio «usurpado» por conquista a los eventuales derechos del arzobispo no era casual ${ }^{55}$.

La comparación de estas intervenciones condales con otras suyas en fechas y lugares cercanos muestra el sentido o valor de las retenciones de rentas, puesto que respondían a las posibilidades o pretensiones de dominio que el señor, aquí el conde, tenía en cada lugar. Así su intervención en la carta de población de Espinavessa en 1155 se aleja de las exigencias en el ámbito de Siurana. Esta concedida conjuntamente con el arzobispo de Tarragona, reservaba los diezmos y primicias a la iglesia tarraconense, mientras que el dominio restaba sujeto a ambos señores. En esta ocasión, el conde se sometía a las exigencias del prelado, quien también retuvo diezmos y primicias en las cartas de población que libró en su jurisdicción directa, como en la Selva —Villa Constantina 1164-o en Mas Calbós6. Además en el instrumento de la Selva se instaba a los habitantes a jurar fidelidad al arzobispo, que ya prestaban los habitantes de la ciudad y del Camp, siendo un testimonio temprano de la exigencia del juramento a la población ${ }^{57}$.

En otra ocasión Ramón Berenguer IV concedió a Pere Berenguer de Vilafranca la «vicaria» y la batllia de Duesaigües en 1155, para que consolidase la ocupación, y le asignó la cuarta parte de las rentas, de la justicia, el diezmo, las cuarteras, el mercado y el horno, siguiendo un modelo de reparto extendido en lugares vecinos de la Marca. La diferencia entre esta intervención condal y otras suyas respondía a que impuso su dominio en un sitio ya feudalizado bajo la autoridad de Pere Berenguer y, por tanto, el principal objetivo era definir su dependencia a cambio de la concesión del cargo, no sin recabar una parte importante de rentas ${ }^{58}$.

55 En 1173 un acuerdo confirmaba al prelado la obtención de diezmos y primicias en el Camp de Tarragona y por este se promovió la restitutio apendicis montaneorum de Prades facta per eundem regem, que confirmaba que la intervención del conde de Barcelona había «interferido» en un ámbito vinculado al señorío arzobispal de Tarragona. De todos modos, Ramón Berenguer IV cobró diezmos o los compartió con la iglesia en otros lugares, SALRACH, J.M.: «La renta feudal en Cataluña en el siglo XII: estudio de las honores, censos, usos y dominios de la casa de Barcelona», en Estudios sobre renta, fiscalidad, y finanzas en la Cataluña bajomedieval, Barcelona, 1993, pp. 29-70/ 55.

${ }^{56}$ Cartas, pp. 156-157 —Espinavessa estaba en el término de Valls_, pp. 182-3 y pp. 193-4, respectivamente.

57 ...et faciatis inde nobis homagium et iuretis fidelitatem sicut ceteri habitatoris Tarracone et territori...

58 Cartas, pp. 151-2. Poco después el conde otorgó la carta de población a los habitantes de la localidad y a la vecina Vilaverd, donde aprovechó para manifestar su dominio mediante la retención de rentas que eran nuevas respecto de las compartidas con el batlle, como las fraguas o las primicias e incluso con la retención integra de los diezmos cuando en la concesión de vicaría se había reservado las 
La iniciativa intervencionista condal coincidió con el cambio de nombre del lugar, que se llamaría Vilasalva, reflejando la condición de seguridad o franquicia que le atribuyeron los poderes que se desplegaban en el lugar.

Asimismo, Pere Berenguer de Vilafranca se perfilaba como el hombre de confianza de la corona en este sector extremo del Camp y de la Marca - Conca de Barberà-, por lo que el rey Alfonso le encomendó el traslado de la localidad de Duesaigües o Vilasalva a Montblanc, en 1163. Las condiciones impuestas al vicario eran casi las mismas que había obtenido en Duesaigües, y así alcanzaba la cuarta parte de las mismas rentas, aunque las stachamenta integramente ${ }^{59}$. El reparto de rentas se produjo de forma similar en la concesión de Rocabruna a Guillermo de Torroja por parte del arzobispo y del rey en 1171, quien obtuvo la cuarta parte de los beneficios judiciales y del resto de derechos señoriales. Esta localidad se situaba explícitamente en el territorio de Tarragona, aunque su posición vecina a las estribaciones de las Marcas, como Duesaigües y Vilaverd, explica que las condiciones de reparto de las prestaciones económicas en estas localidades fuesen cercanas a la de los ámbitos contiguos desde tiempo atrás. Por tanto, seguramente las actuaciones de los grandes señores seguían las huellas de pactos o situaciones anteriores, o al menos emulaban fórmulas organizativas cercanas ${ }^{60}$.

Otros testimonios corroboran claramente como Ramón Berenguer IV se «impuso» como señor en lugares donde otros habían emprendido el dominio a título personal como aprissores, de forma parecida a las actuaciones del conde de Urgell en el Mascançà. Así sucedió en Vilanova de Prades, dónde constaba que Pere, capellán de Pinós, lo había aprehendido y «recibido» de Ramón Berenguer IV. Pese a la presunta vinculación con el conde, la situación requirió de una confirmación de la mencionada donación y de los derechos dominicales a su sobrino y heredero, Pere de Avellà, efectuada por Alfonso el Casto y su castellano en Siurana, Albert de Castellvell en 1163. En este sentido, la ratificación servía para reactivar o introducir los derechos de la corona y su representante, más allá de una mera sanción protocolaria, que además sugiere la incapacidad de Ramón Berenguer IV de introducirse en un lugar feudalizado anteriormente ${ }^{61}$.

Como se ha visto Ramón de Cervera había librado a Pere de Pinós capellanías con términos y heredades como la de Albarca, cercana a Vilanova de Pra-

tres cuartas partes. Además omitía los derechos de este, de quien recordaba que había repartido las heredades, y pese a ello Ramón Berenguer IV recalcaba ...ibi erit pro me, Cartas, pp. 153-4.

59 Cartas, pp. 172-3.

${ }^{60}$ Cartas, pp. 200-202; de forma semejante a Duesaigües donde Pere Berenguer ya había intervenido en la feudalización de los términos con anterioridad al pacto con el conde, Rocabruna, también parece un lugar ocupado o señorializado, pese a que se indica que es yermo. La referencia a la dotación de una isla con unos molinos, en los que los señores retenían la mitad, así como la quinta parte de los frutos desvelan la explotación y seguramente la fijación de rentas con anterioridad al instrumento de infeudación.

${ }^{61}$ Cartas..., p. $175 ;$... et propter aprisionem et donationem quam prefatus capellanus avunculus tuus ibi fecit et habuit de patre meo Raimundo comite Barchinonensis.... 
des, y explicaría la razón de su dominio o presencia allí. En la concesión, los Cervera se reservaron la mitad del diezmo, y luego el rey Alfonso retenía asimismo la mitad, en contraste con la totalidad que su padre se asignó en este territorio de Siurana. Además la situación irregular se deduce de la omisión de la concesión de R. Cervera en las donaciones regias, quien tenía lo transferido a Pere de Pinós per aprisione aut per ullasques voces. Precisamente el recorte de derechos adquiridos o administrados por otros señores a partir de la intervención condal, explicaría el porqué de unas condiciones distintas a las definidas por Ramon Berenguer IV en el ámbito de Siurana. Esto explicará la elocuente confirmación del senioraticum al beneficiario que no se llevó a cabo en el mencionado territorio. Asimismo Pere d'Avellà participaba en la tercera parte de la mitad de los diezmos del rey y de la justicia en contraste con la retención total de los diezmos por el conde en esta región de Siurana, aunque su jurisdicción quedaba limitada a la presencia del castellano de Siurana en los juicios.

En conclusión, la cúspide señorial se consagró en el proceso de la feudalización del Camp de Tarragona no sin enormes tensiones, y de forma parecida actuó el conde en el territorio de Ciurana. Los grandes señores imponían su autoridad y definían un nuevo mapa de poderes dependientes, basado en núcleos fortificados donde se concentraba la población. Esta fue una estrategia fundamental de las intervenciones señoriales y el proceso culminó mediante la concesión de cartas de población en décadas sucesivas. La concentración del poblamiento en buena parte de la Cataluña Nueva resultó de la propia consolidación del poder feudal, capaz incluso de reorganizar y ordenar la ocupación poblacional, y cuyo objetivo era ejercer un mayor y mejor control sobre la población y las cosechas. El reconocimiento del señorío eminente se exigía a menudo de forma exclusiva y a través de diversas manifestaciones, como las rentas o el juramento de fidelidad, que cada vez más involucraba a todos los dependientes, y de este modo el señor estaba más presente pese a que cada vez estuviese más lejos, o fuese más poderoso.

\subsection{La intervención condal y la herencia andalusí en la feudalización de Tortosa y Lleida}

Las iniciativas feudalizadoras en Tortosa y en Lleida fueron distintas a las del resto de la Cataluña Nueva, por la envergadura de la empresa militar y sobre todo porque los señores se impusieron en dos ciudades andalusíes. Cabe destacar la complejidad y trascendencia de la empresa de Tortosa, una de las principales ciudades de la «frontera superior», cuya importancia explicaría la participación de los genoveses en plena expansión mercantil mediterránea.

En ambos casos, el conde de Barcelona alcanzó compromisos para la formación del ejército feudal, que rigieron las posteriores dotaciones de patrimonio a los participantes. Los principales gratificados en Tortosa fueron Guillem Ramon de Montcada, el Senescal, los templarios y la República de Génova, que 
obtuvieron partes importantes del territorio. En Lleida, de menor entidad urbana que Tortosa, el conde de Urgell quedó sujeto al vasallaje del de Barcelona al recibir en feudo la tercera parte de la ciudad y territorio mediante un pacto como los de Marca62. La distinta orientación del gran reparto en sendas ciudades respondía a que Ramón Berenguer IV manejó la infeudación de Lleida para redefinir su vinculación con Armengol VI, y así poner fin a las actuaciones independientes desarrolladas por el poderoso conde de Urgell en el progreso de la organización feudal en y desde su condado.

En estas regiones, los procesos de feudalización estuvieron marcados por la exigencia de apoderarse de las propiedades musulmanas, y además en las dos ciudades de someter a los habitantes en un ambiente distinto y complejo como el urbano. Tales condiciones obligaron a introducir fórmulas de ocupación eficaces en un medio potencialmente hostil y, por tanto, el establecimiento señorial debía hacerse sin conflictos, puesto que hubiesen puesto en riesgo la definición de los poderes como sucedía en territorios cercanos. De esta forma, el equilibrio entre los señores era una condición indispensable para eliminar la oposición de los conquistados, que además se atajó con el exilio de muchos musulmanes, el sometimiento a la cautividad y la aquiescencia de algunas de sus elites.

La situación de «emergencia» explica la necesidad que tuvo el conde de atribuirse un papel rector, preeminente y especialmente vinculado al nuevo sentido de autoridad «pública», que rebasaba las características del lugar principal derivado de su dirección de la empresa militar. Así, Ramón Berenguer IV se arrogó la función de repartir las tierras conquistadas en las cartas de población de Tortosa y de Lleida, que era una verdadera innovación y reflejaba la importancia de la autoridad condal ${ }^{63}$.

Como en otros lugares del Occidente feudal, las nuevas fórmulas políticas como las derivadas de la teoría del principado, procuraban un marco de estabilización o pacificación de la aristocracia feudal, y Ramón Berenguer IV emprendió su aplicación de forma significativa en las regiones tomadas a los musulmanes. La afirmación de su poder comportó la fijación de las primeras

${ }^{62}$ No desarrollaremos el tema del reparto de ambas ciudades; para Tortosa puede verse Pagarolas, L.: La comanda del Temple de Tortosa: primer periode (1148-1213), Tortosa, 1984; SHIDELER, J.C.: Els Montcada: una família de nobles catalanas a l'Edat Mitjana (1000-1230), Barcelona, 1987, pp. 186 y ss.; VIRGILI, A.: «Ad detrimendum Yspanie. La cruzada de Turtusa y la feudalización de la región de Tortosa» en L'Incastellamento. Actes de rencontres de Gérone et de Rome», Roma, 1998, pp. 109-113 y Ad Detrmientum Yspanie. La conquesta de Turtusa i la formació de la societat feudal (1148-1200), València, 2001, entre otros y para Lleida, LlaDONOSA, J.M.: La conquesta de Lleida, Barcelona, 1990, desde p. 28 y AA.VV.: Lleida: de l'Islam al Feudalisme, Lleida, 1996, aunque muy breve y sólo divulgativo.

${ }_{63}$ En Tortosa indicaba sicut uniquique dabo por donationes meas et cartas quas facturus sum vobis... y en la de Lleida eas dabimus per cartas nostre donationes, Cartas, pp. 121-126 (1149), y pp. 129-132 (1150), respectivamente. Sin embargo en el caso del distrito de Siurana, conquistado y feudalizado por el conde, confió el reparto de tierras y casas a Bertrà de Castellet, in antea dederit meus cavallerius Bertrandus de Castellet qui est in Siurana, Cartas, pp. 147-9. 
instituciones urbanas, a su vez necesarias en un contexto socioeconómico complejo, cuya máxima expresión fue la curia como órgano regulador de la vida ciudadana, que ocasionalmente funcionó como contrapeso de la actividad de los señores.

El conde de Barcelona puso las bases del gobierno municipal sólo un año después de las conquistas, creando la mencionada curia encargada de la justicia, y promulgando las primeras normas de legislación local en las singulares cartas de población de Tortosa y Lleida ${ }^{64}$. Además, para la transición de la ciudad andalusí la feudal buscó cierta complicidad, o al menos aceptación de algunos de los musulmanes que subsistieron a los efectos devastadores de la conquista, a quienes procuró garantías y reconoció sus bienes o la libertad de movimiento en la capitulación de Tortosa, aunque no se aplicó. Pese al teórico respeto hacia los ocupados, se les obligó a residir en un barrio en los arrabales de la ciudad como sucedería también en Lleida, y además sus dignatarios quedaron vinculados a la dependencia del conde ${ }^{65}$.

La sintonía entre el desarrollo de la potestad condal y el gobierno de las ciudades en las tierras conquistadas se refleja en la proximidad de algunas disposiciones de sus cartas de población con otras de los Usatges de Barcelona. Teniendo en cuenta la trascendencia de este código en la definición del nuevo orden político perseguido por Ramon Berenguer IV, resulta evidente que las normas de Tortosa y Lleida se ceñían y participaban del mencionado programa político.

La primera medida legislativa de las cartas velaba por la paz, ya que la provocación de una arma debía resolverse ante la curia o mediante multa, y este propósito armonizador inspiraba otras medidas que buscaban eludir los conflictos, fijándose nuevamente la curia como garantía. Una nueva dimensión de justicia se imponía, y aunque administrada por los «prohombres» o señores feudales, trataba de aplicar normas ajenas a la arbitrariedad. Además, la fijación de la curia desbancaba el modelo de un mapa complejo de parcelas de poder derivadas del reparto de jurisdicciones que se había impuesto en la Marca, e incluso de forma distinta en Tarragona.

En las donaciones condales de los primeros años de ocupación cristiana,

${ }^{64} \mathrm{La}$ carta de Lleida la concedió con el conde de Urgell, aunque su contenido era tributario a la de Tortosa, FonT, J.M.: Estudis sobre els drets i institucions locals en la Catalunya medieval, Barcelona, 1985, pp. 141-161.

${ }_{65}$ Ramón Berenguer IV quería asegurarse la fidelidad de los líderes musulmanes, como se refleja magníficamente al definirlos como vasallos, equiparándolos a los prohombres de Tortosa, ...et affidiavit comes ad alguaçiles, et alcadis et alfachis in lures animas et in lures hereditates et illis quod sedeant suos fideles vasallos sicut alios bonos homines de Tortosa... Con el mismo propósito les confirmó expresamente sus bienes, de modo que atrayendo la fidelidad de quienes lideraban la sociedad musulmana sometía al resto de la población con mayor facilidad, Codoin, IV, pp.130-135 (1148). La fijación de las dos aljamas fuera de las murallas perseguía reducir el peligro potencial de un levantamiento, MUTGÉ, J.: L'aljama sarrä̈na de Lleida a l'edat mitjana. Aproximació a la seva història, Barcelona, 1992, p. 3. 
Ramón Berenguer IV y en menor medida Armengol VI no retenían rentas territoriales ni jurisdiccionales, a diferencia de lo que sucedía en las concesiones de la Marca o del Camp de Tarragona en las mismas fechas ${ }^{66}$. Incluso en las cartas de población el conde manifestaba que no se reservaba nada en las propiedades libradas en Lleida, o de forma más genérica en Tortosa, excepto la novena sobre la sal y estaños. Sin embargo y, en contraste con la renuncia explícita a las retenciones en las dotaciones de dominios o en los instrumentos poblacionales, el conde reclamaba la dependencia personal, recordando al beneficiario su fidelidad o que el donativo respondía ad servitium y se instaba su vinculación mediante un salva mea fidelitate ${ }^{67}$. Además, en sendas cartas de población, los habitantes de Tortosa y de Lleida declaraban su fidelidad al poder condal y significativamente en la parte final del documento según una fórmula prestada o derivada de las convenientiae. Asimismo, en la de la Lleida, los condes reivindicaban la dependencia o la fidelidad y precisamente como salvedad a su compromiso de no retener nada: ...preter fidelitatem et solam rectam iustitiam.

De la misma manera el conde se inhibió de la exigencia de derechos en las donaciones como una estrategia para estimular el establecimiento de los nuevos señores, quienes podrían disfrutar de sus dominios de forma integra, siendo de nuevo una fórmula inusual respecto de otras actuaciones suyas. Asimismo, en la mayoría de los primeros donativos condales, se concedía una casa en Tortosa o Lleida junto a las tierras, habitualmente del mismo propietario andalusí, expresión de la estrategia de reocupar las ciudades con personas «fieles» o cristianas, tras el abandono forzado o no de los musulmanes ${ }^{68}$. Incluso a veces se exi-

66 De forma excepcional se especificaba sine ullo retenimento nunc et in perpetum en alguna dotación condal, aunque también era singular que se manifestase la retención de la tercera parte de los frutos en la concesión de molinos en un lugar de Lleida por parte del conde, Col.lecció Gardeny, pp. 147 y $135-6$ respectivamente.

67 Las referencias a personas fieles o a la obligación de ser fieles consta en algunas concesiones, y se relaciona con personajes destacados, como Pere de Rajadell, de quien se especificaba propter servicia multa que michi fecisti, Diplomatari Tortosa, p. 61 (1149), y otra dotación al mismo en términos parecidos, p. 71. Las mismas expresiones aparecían en los donativos al escriba Ponc, Diplomatari Tortosa, pp. 62, 68 - o en otra versión documental 70-. Albert de Castellet obtuvo un patrimonio en Lleida ad servitium et fidelitatem meam, y salva mea fidelitate... (1149), Col.lecció Gardeny, p. 113; o Guillem de Sadaó en Ascó en los mismos términos (1152), Col.lecció Gardeny, p. 129. En otros instrumentos, en menos de la mitad de los conocidos, el conde exigía la fidelidad como en las donaciones a Pere Guillén, a Ademar, a Pere Blanxard, a Guaspai, Diplomatari Tortosa, pp. 57, 58, 73, y a Arnau Torroja, Ramon Monells, Arnau Gras, Col.lecció Gardeny, pp. 110-111, 130, $220-221$.

68 Sirva como ejemplo la transferencia de las casas de Abnalgenen en Tortosa con todo cuanto tenía dentro y fuera de la ciudad tam in campis, quam in ortis tam in terris quam in vineis, precisando la variedad de la explotación agraria -(1149), Diplomatari Tortosa, p. 61 y los referidos en la nota anterior; o en Lleida como el conjunto obtenido por Ramon Castellar, con las casas en Lleida de Avingallifa cum omnibus tenedonibus ac pertinentis (1150), Col.lecció Gardeny, p. 119 u otros pp. 113, 114, 116-117, 119, 129, etc.; Diplomatari, pp. 114-115 y LBSC, pp. 57, 58, 58-9 y 114-115. En algunas oportunidades el lote se configuraba con las casas de uno y las tierras de otro como en la donación a Pere Oleguer, quien obtuvo domos in Tortosa qui fuerunt Abrabim Zegeil cum omni honore...et 
gía a los destinatarios de bienes que ...sitis habitatores Dertose69. La ocupación cristiana de Tortosa y Lérida perseguía mantener el papel central en su territorio característico de las ciudades musulmanas, o en una amplia zona de «intensa» explotación rural, y por esto se priorizó el «restablecimiento» de la población o de la actividad económica urbana a la ocupación feudal de sus amplias regiones.

Precisamente Ramon Berenguer IV aceleró el proceso de dotación de bienes por la necesidad de consolidar la presencia cristiana. De esta forma, el grueso de concesiones en los ámbitos de las dos ciudades se concentró en poco más de un quinquenio, lo que mostraba una nueva diferencia respecto del goteo de donaciones que se estaba produciendo en las regiones periféricas, incluso en el ámbito del antiguo valiato de Siurana ${ }^{70}$. Todas estas iniciativas aseguraron la continuidad del modelo urbano, que se diferenciaba de las intervenciones en las Marcas, o incluso en el ámbito de Tarragona ${ }^{71}$.

La reactivación de Tortosa requería del dominio del litoral para mantener su proyección comercial y garantizar su seguridad, neutralizando los ataques marítimos musulmanes, y por ello el conde de Barcelona efectuó las primeras grandes donaciones de toda la amplia región dertosense en enclaves de la franja litoral. La generosa concesión del dominio de Amposta a los hospitalarios en 1150 fue un hito en el establecimiento de la presencia feudal en la desembocadura del Ebro, y el interés condal de asegurar la defensa de este lugar estratégico se tradujo en la contribución de 2000 morabetinos para la fortificación - fórmula insólita en el resto de donativos-. Además, la incorporación de los freires respondía a la función militar, defensiva o de vigilancia que iban a desarrollar o que el conde les atribuía. Otras donaciones contemporáneas efectuadas por Ramón Beren-

dono tibi hereditatem illius sarraceni vocatur Avingenia en 1151, Diplomatari Tortosa, p. 74, o en la concesión a Ramon de Muls, p. 78. De los antiguos propietarios de la dotación a P. Oleguer, cabe observar que el de las casas ya no estaba y el de la heredad sí. También hubo donativos en que sólo se trasfería la casa, LBSC, pp. 50, 52. Sobre el fenómeno de las migraciones musulmanas en general, MARíN, M.,: «Des migrations forcées: les 'ulama d'al-Andalus face à la conquête chrétienne» en L'Occident musulman et l'Occident chrétien au Moyen Âge, Rabat, 1995, pp. 43-60/50.

${ }^{69} \mathrm{La}$ exigencia de hacer residencia en Tortosa sólo figura en algunas donaciones condales, y nunca en las dirigidas a los grandes señores, como en la destinada a Pere Guillén, Diplomatari Tortosa, p. 57; o a Pere Blanxard en 1149 p. 69, a quien se reiteró la petición de residencia tras otro donativo, Diplomatari Tortosa, pp. 78-9 (1152); o a Zara y a Pere Santponç en 1154, Diplomatari Tortosa, pp. 97 y 99 respectivamente.

70 Virgili, A.: Ad detrimentum, p. 89; destaca la intensificación de donativos en los primeros cinco años.

${ }^{71}$ El estímulo al ejercicio de actividades estrictamente urbanas se constata en la exención al pago de impuestos de tránsito de mercancías — lezda, portazgo y pasaje — en las dos cartas de población. La centralidad atribuida a ambas ciudades tras la conquista y embrión de ciertos derechos en otras jurisdicciones, contrasta con la configuración coetánea de localidades como la de Espluga, donde se desarrollaron dos entidades jurisdiccionales, la Sobirana y la Jusana, relativas a cada uno de los dos señores aunque era una sola localidad, AltiSENT, A.: Un poble, pp. 158-162. 
guer IV como la Aldea (1148), la Rápita (1150) o Camarles (1150) cubrían el arco interior de la región predéltica ${ }^{72}$. Igualmente, en la misma década, el proceso feudalizador en el territorio tarraconense se desarrolló básicamente en el litoral o cercanías, lo que hace pensar en un programa amplio o complejo de defensa del litoral ${ }^{73}$.

Las intervenciones del conde o de los señores feudales se impusieron a las fórmulas de la organización socioeconómica andalusí, aunque algunas fueron utilizadas por Ramón Berenguer IV para una rápida dominación y explotación efectiva de los recursos. No obstante la mencionada táctica, era necesario desmantelar la ordenación social musulmana, que fue substituida por el nuevo orden feudal, aunque condicionado por la herencia andalusí y por los requerimientos de una violenta ocupación. La transmisión de estructuras de organización del territorio o patrimonio andalusíes se evidencia en la utilización de las torres como centro de los nuevos dominios feudales en la región ilerdense, y los castra en la definición de grandes señoríos en la del Ebro.

La elección de una u otra entidad territorial en sendas regiones era una vez más el resultado del programa condal. Así las torres andalusíes de la Ribera catalana del Ebro no se transfirieron a los nuevos señores ni fueron lugares centrales o de referencia en la organización del territorio como sucedía en el Pla de Urgell o en Lleida. Pese a que las torres no fueron centros de feudalización tras la conquista en la zona del Ebro, se perfilaron como núcleos de administración dominical o de población agraria en décadas posteriores y lugares principales de los señoríos en la baja edad media. Por tanto, existió una continuidad en la posición de eje de dominio territorial desde época andalusí, aunque al parecer Ramón Berenguer IV prescindió o eludió dicha función cuando organizó el mapa de señoríos ${ }^{74}$. Esta probable omisión en la elección de las torres andalusí-

72 Archivo Histórico Nacional o AHN, órdenes militares, carpeta 686, n.2; la de la Rápita en Códice 662B, folio o f. 6 del mismo fondo; para la Aldea y Camarles, Archivo Histórico Comarcal de las Tierras del Ebro o AHCTE, cajón Perelló, 48-49 y cajón Camarles, 40, respectivamente.

73 Hay una referencia indirecta a los ataques marítimos musulmanes en Tarragona cuando se consignó una fortificación a la canonjía, y que explicaría la preocupación por afirmar la defensa en el frente litoral en el ámbito meridional de Cataluña: ut ibi sint luti ipsi — los canonjes_ et res eorum ab exercitu navali navigatium sarracenorum, VILlANUEVA, J.L.: Viaje literario a las iglesias de España, XIX, Madrid, (1803-52), pp. 214-6 (1154).

${ }^{74}$ En la relación de donativos condales tras la conquista de Tortosa no aparece indicación a entidades patrimoniales con el nombre de torre, salvo unas pocas menciones a almunia, véase cuadro en Virgili, A.; Ad detrimentum, pp. 101-102; y sin embargo en la donación coetánea del barrio judío de Darracina se incluían diecisiete torres que fijaban el perímetro, Cartas, pp. 126-127, (1149). A pesar del silencio en la documentación emitida por el conde, en el ámbito meridional del Bajo Ebro hubo torres o fortificaciones menores que fueron centro de dominio, e incluso núcleos de subencomiendas del Temple: Aldea, Burjassènia, el Prat o la torre de la Candela. En la otra ribera había la torre de la Carrova con un exarico que confirma su origen andalusí, BONET, M.: «L'Amposta feudal. Poders, societat i economia» en Actes de les Jornades d'Història d'Amposta, Amposta, 2001, pp. 141-180/147 y ss. En plena Ribera había la torre, que adquirió Español —antes 
es como nuevos focos de poder cristiano concuerda con sus iniciativas de control respecto de la clase feudal y de sus manifestaciones belicosas en la región, aunque se enmarca en su política general sobre fortificaciones. Así el conde de Barcelona se arrogó el derecho del consentimiento de la construcción de otros castillos, con lo que se intentaba limitar la proliferación de núcleos de poder local o regional que pudiesen estar al margen de su autoridad, como hiciese al prescindir de las torres ${ }^{75}$.

Sin embargo, si bien Ramón Berenguer IV no integró las torres como entidad patrimonial-territorial en la feudalización de la Ribera del Ebro catalana, él y su hijo concedieron grandes distritos castrales o castra —algunos identificados o identificables con busun - mayoritariamente a templarios y hospitalarios en las tierras del Ebro, convirtiéndose en centros fortificados de las encomiendas en la frontera con Al-Andalus ${ }^{76}$. De este modo se definía un sistema de defensa de gran envergadura, confiado a instituciones fieles como eran las órdenes mili-

de Albozacag, luego la Torre del Español-, Cartas, II, p. 802 y otras documentadas como el Corder, la Merla, Xerta, Tivenys, Coll del Som, por Balaña, P: L'Islam a Catalunya (segles VIIIXII), Barcelona, 2002, p. 72; y en la zona del Priorat a las ya conocidas de La Figuera, Cabassers, añadimos las de Vensilló y Vinquin -Aviaquin-, Cartas, pp. 169-170, cercanas a La Figuera. También en el ámbito de Lleida, Ramón Berenguer IV concedió torres en pocas ocasiones, pero en la región se documenta un mayor número de estas y después de la conquista respecto de Tortosa y la Ribera de Ebro, donde respondían a las necesidades de ejercer el control señorial desde altura en un terreno llano y sin la orografía del valle del Ebro. Algunos ejemplos son la de Avinyana, o el lugar de Torres — de Segre-, Diplomatari, pp. 140 y 141 - 1153 - o una en Fontanet — Lleida, 1155-Col.lecció Gardeny, pp. 157-8; y significativamente en una relación de los censos que tenía la encomienda de Gardeny algunas torres englobaban varias heredades y tenían el nombre de quien era o había sido su señor cristiano: torre de Humberto, de Bernat Ferré, de Sales; de Riudoveles, de Forcada, de Pere Oromir, de Guilabert; de Pere de Puigalt, Col.lecció Gardeny, II, 1065-1069. Parece que tal organización social del espacio era consecuente con la andalusí.

75 Según se explica en el usatge 73, que se refiere a la construcción o ampliación de castillos así como la de iglesias o monasterios en los distritos castrales, aunque el articulado es preciso al respecto del pleno poder del señor en el castillo, VALLS, F.: op. cit., p. 92. Las monarquías feudales en otros lugares limitaban la proliferación de fortificaciones, como hiciese Enrique I de Inglaterra pocas décadas antes.

${ }^{76}$ En la comarca más meridional de Cataluña, los dos distritos castrales andalusíes: Amposta y Ulldecona fueron transferidos a la orden del Hospital en 1150 y 1178 respectivamente. En el caso de Ulldecona hay evidencias arquitectónicas y arqueológicas de su vinculación a los vecinos husun levantinos estudiados por P. Guichard; AHN, órdenes militares, carpeta 686, 2 y 3-6-7. En el castillo de Miravet, también se ha constatado la existencia de la doble albacara andalusí, CURTO, A.: «Resultats de les prospeccions arqueològiques al castell de Miravet» en Acta Arqueológica de Tarragona, (Tarragona) 1 (1987-88), pp. 49-61, y también el cerano de Ascó fue hisn, según D. Bramón y cita BALAÑA, P.: op. cit. La donación de Miravet efectuada por Ramón Berenguer IV significaba la transferencia de distintos distritos castrales de la zona además del recién conquistado de Miravet: castris et villis, videlicet castrum de Algars et castrum de Batea...et castrum de Corbera et de Gandesa...et castrum de Pinello...et de Resquera, Codoin, IV, pp. 208-211. No se puede identificar mecánicamente estos castra con los husun, ya que el conde definió el ribat de la Rápita como castrum Rapite. 
tares, y que tiene su manifestación más elocuente en la concesión de la fortificación urbana de Gardeny (Lleida) al Temple y su participación en la defensa de La Suda (Tortosa) — tras haber sido del Senescal- De nuevo se constata la reutilización de entidades de control del espacio musulmanas, y significativamente castralizadas por parte de los poderes feudales, que reitera la voluntad o necesidad de prolongar formas de organización del territorio anteriores, aunque adaptadas a las exigencias u objetivos políticos tras la conquista.

Además de las grandes unidades administrativas o patrimoniales, se produjo un reparto menor caracterizado por una traslación exhaustiva de los patrimonios andalusíes a los nuevos propietarios feudales. Como se ha indicado esta se concretó en un número importante de donaciones de un lote de propiedades de un andalusí con casas y tierras, que refleja como el parcelario de la época cristiana era más o menos fiel al de la anterior musulmana. Asimismo se buscó mantener el ritmo y la forma de las explotaciones andalusíes con la misma voluntad continuista, que se reflejó en las cuantificaciones de las cosechas de las propiedades de musulmanes en algunas cartas de traspaso, y que constituía una singularidad en la documentación contemporánea. Así se concretaban las producciones, como en la donación a dos hermanos de illas chasas in Tortosa de Abmed Abenceibal, cum suo bonore, quem habet in Berchad, unde exunt II os. quintars de ficubus, et de racemis $X X X$ chintars, et sunt ibi olivarie trunchate que dare solebant $L$ chantars de oleo, et habet in campor de seminatura de XXIII quarteras ${ }^{77}$. Los productos mencionados son comunes a los de otras descripciones de este género, a saber aceite, uva, higos y cereales. La diversidad o especificidades de la cosecha muestran que la agricultura andalusí tuvo una orientación mercantil, y los conquistadores mantuvieron y afianzaron mediante la exigencia de plantar ciertos cultivos en las cesiones ad plantandum ${ }^{78}$. Una vez más, la herencia musulmana marcó el desarrollo de un modelo de economía agraria mercantilizada.

La transferencia de las propiedades andalusíes a las nuevas cristianas se produjo implicando a un cierto número de musulmanes en la explotación, como los antiguos propietarios convertidos en exáricos, algunos establecidos como arrendatarios o cautivos, e incluso unos pocos como propietarios por algún tiempo, y todo para asegurar la continuidad de la actividad agraria ${ }^{79}$. Los que

77 Diplomatari, p. 114.

78 En la producción reseñada de Ahmend Abenceihal se constata que la de aceite o vino excedían al consumo familiar —entorno a 550 litros de aceite y más de 1200 kilos de uva - y presumiblemente tenía una salida mercantil. En la bibliografía se suele referir un crecimiento de la explotación vitícola tras la conquista, aunque J.M. Salrach demuestra su importancia en época andalusí, que nos permite abundar en tesis de continuidad más que de ruptura: «La viticultura de la Catalunya Nova després de la conquesta: societat i mercat en el segle XII» en Acta bistorica et archaelogica mediaevalia, (Barcelona) 22 vol. 2 (2001), pp. 229-256/230. Además destaca las fuentes con menciones a las cosechas, que hemos singularizado, para aproximarse a la agricultura andalusí, p. 231.

79 Algunos propietarios como Asmet Abenhudna fueron tomados como exaricos en sus antiguas explotaciones, LBSC, p. 51 (1151) y su condición de exarico en Diplomatari Tortosa, pp. 
quedaron eran la memoria viva, a quienes se recurría ocasionalmente cuando había discusión sobre dominios, términos u otros aspectos ${ }^{80}$. De otra parte, se documenta el conocimiento exhaustivo de las entidades territoriales o patrimoniales antes y poco después de la conquista procedente de informadores musulmanes en respuesta al interés de los conquistadores.

Las particularidades de la transición nos muestra un mundo andalusí que fue asimilable al conquistador, tanto en la organización del territorio como en las propiedades agrarias, que algunas veces integraban varias parcelas explotadas por terceros, y ambos aspectos son expresiones del orden políticosocial. Todo esto lleva a concluir que existía la posibilidad o la voluntad de asimilación de la organización andalusí y que se dieron las condiciones para la adaptación de las tierras conquistadas al nuevo orden feudal. Dejando de lado el debate sobre la señorialización de la sociedad musulmana, resulta evidente que algunas formas de ordenación político o administrativa, de propiedad o de sometimiento de otros grupos sociales fueron, en parte, referentes para los conquistadores y trascendieron a la ocupación cristiana. La voluntad de asumir la realidad andalusí se descubre en el programa condal de transferencia del conjunto de bienes de un musulmán a un cristiano, y pese a que introdujo variantes, su propósito de transmisión de equivalentes era tal que si se desviaba del proyecto y añadía más tierras lo justificaba por escrito, argumentando que las concedidas eran insuficientes ${ }^{81}$.

En el proceso de traspasos organizado por Ramón Berenguer IV, algunos testimonios son especialmente elocuentes de su planteamiento, como el de los bienes de la mezquita mayor y de las otras del obispado de Tortosa transferidas

329-330, aunque se mantuvo como propietario hasta 1151. También en 1173 se reconocía que la titularidad del honor había sido de su exarico Avincomprad, LBSC, p. 176; u otra hacienda que había sido del exarico; Abochazuz, Diplomatari Tortosa, pp. 172-3; o en Lleida se daba a un musulmán, Ali Ferrer in servizio de ipsa sort, Col.lecció Gardeny, p. 283. Resulta oportuno destacar como al cabo de veinte años de las conquistas, todavía existían propietarios musulmanes que vendían sus tierras, como hicieron Obocar y hermanos con sus posesiones en Fontanet al Temple de Gardeny, Col.lecció Gardeny, pp. 509-510; o un poco antes en 1176 Mafumet Abofad lo Calbo, ibidem, pp. 450-451. En dicha oportunidad, firmaron como testigos algunos musulmanes y Mafomet, alcayde de Lleida, que muestra la supervivencia de una elite musulmana, por minoritaria que fuera. En el distrito de Ulldecona, Muhammed ben al-Husayn rubricaba una donación de derechos en el término en arábigo, Diplomatari, pp. 232-3.

${ }^{80} \mathrm{El}$ rey resolvió en una sentencia la titularidad de la torre en disputa, y que quienes la poseían lo podrían demostrar por carta o mediante el testimonio del exarico (1189), DelavilLE, J.: Cartulaire général de l'Ordre des Hospitaliers de Saint-Jean de Jérusalem (1100-1310), París, 1894-1906, I, pp. 554-555.

${ }^{81}$ En la donación a Pere Guillén, se indicaba ipsas chasas de Abenelia...honore de Aberramia et quia non abundat terra ad seminandum addo tibi ipsum bonorem de Abe Exeniz, Col.lecció Gardeny, p. 57 (1148). Otra valoración semejante indicaba et quia paucissimam terram habet ad seminandum dono tibi...totum quod ibi tenuit et habuit, Col.lecció Gardeny, pp. 68-9 u otra en p. 70. En el traspaso de las casas del alamín Asmet Avinferre, se argumentaba que puesto no tenía tierras de labor, se añadían dos heredades de otros dos musulmanes, LBSC, pp. 58-9 (1151). 
a la catedral, o igualmente los de las iglesias que antes habían sido mezquitas, al de Lleida ${ }^{82}$. La precisión a los alodis como parte de esta propiedad demuestra que el cambio de titularidad afectó a su vez a las explotaciones agrarias, evidencia de la identificación del patrimonio de la mezquita con el de la iglesia además de la significativa de los espacios sagrados.

En definitiva, las actuaciones condales respondieron a un contexto absolutamente excepcional, que justifica las diferencias respecto del resto de los territorios feudalizados o refeudalizados en estas fechas. Sin embargo, algunas iniciativas que procuraban favorecer la ocupación o su estabilización cambiaron de rumbo cuando el objetivo estuvo más o menos asegurado, y entonces se introdujeron fórmulas comunes con las otras regiones. Así, las retenciones de dominio, que el conde no había exigido al librar dominios, fueron activadas cuando los señores beneficiados con ellos empezaron a infeudarlos y fijaron dependencias más estrictas.

Las intervenciones de Ponç, escriba del conde, muestran algunas de las pautas de la fijación de nuevas dependencias personales posteriores a las iniciativas condales. Ramón Berenguer IV había otorgado a Ponç casas y tierras en Lleida antes de la conquista, y luego casas y heredades en el ámbito de Tortosa ${ }^{83}$. Sus obligaciones en la corte le alejaron de la posibilidad de gestionar dichas propiedades y las infeudó. Así en 1152, el escriba libró un campo de Lleida a dos personas que eran vecinos del mismo, y fijó una retención de la tercera parte de las rentas, correspondiendo las dos terceras restantes a los destinatarios. Además el conde legitimó la concesión, y muestra que actuó como señor eminente pese a no haber hecho uso de la retención de dominio.

Este acuerdo se asemejaba a los pactos entre privilegiados como las convenientiae antes comentados, y siguiendo este modelo los recipiendarios reconocían la fadiga de treinta días y tras un convenimus al final del documento los derechos del donante, que era una expresión de su reconocimiento de fidelidad hacia Ponç. No obstante, las referencias a la fadiga y al censo anual fueron características de los contratos de establiment y, por tanto, pese al formato de infeudación, el instrumento presentaba elementos esenciales de la principal fórmula contractual del medio agrario pleno y bajomedieval ${ }^{84}$. Asimismo dispositivos típicos de las con-

82 Diplomatari Tortosa, pp. 75 y 64-65 respectivamente; en el caso de Tortosa una confirmación del 1178 reiteraba los derechos de la catedral en los bienes de las mezquitas ...tam edificatas quam desertas cum omnibus alodiis..., pp. 377-380. De la dotación al cabildo de Lleida se deduce que las mezquitas son reutilizadas como iglesias, aunque el texto sólo advierte que dichas iglesias eran llamadas mezquitas, y en cuanto a los patrimonios transmitidos con tierras y alodios indica ...sicut melius habuerunt in tempore sarracenorum... La fecha de concesión del documento el 30 de octubre de 1149, una semana después de la rendición, descubre un planteamiento de substitución simbólica de los centros de dirección ideológica por los nuevos, en vez de tratarse de una mera transferencia de espacios religiosos.

83 Diplomatari Tortosa, pp. 62 y 68- 69.

${ }^{84}$ La petición del censo de dos gallinas es explícita y diferenciada del reparto de rentas y del señorío ...salvo senioratico suo et sua tercia parte et salvo censo predicto, Diplomatari Tortosa, pp. 79-80. 
veniencias desaparecían en las infeudaciones que proliferaban en los ámbitos conquistados, como las exigencias militares y el reparto de los derechos jurisdiccionales.

El tránsito de una fórmula documental a otra refleja los cambios en las definiciones de las dependencias personales en tierras de conquista, donde las exigencias de las obligaciones militares o judiciales, fundamentales en las vinculaciones vasalláticas, se hicieron laxas, mientras que todavía se reclamaban en las Marcas y en Tarragona. El cumplimiento de sendas obligaciones no desaparecía, pero tenía una orientación distinta y no estaba circunscrito al bien obtenido. Pese a ello, cabe destacar la existencia de múltiples referencias a la fidelidad de los destinatarios de las infeudaciones de Ponç, que incluso exigía directamente a la persona encargada de trabajar la tierra dependiente de los beneficiarios, a la vez que se le recordaba el cumplimiento de los compromisos de satisfacción de las rentas ${ }^{85}$. Una vez más se manifiesta el binomio dependencia-prestaciones, pero en esta ocasión y pese a los intermediarios, el señor quería comprometer los pagos a quien finalmente los hacía efectivos. Ciertamente se perseguía una jerarquía operativa, y así el payés quedaba sujeto explícitamente al propietario a su vez que a los intermediarios.

Dos años más tarde, Ponç concedía sus casas y varias unidades de tierras de modo parecido, y se otorgaba parte de la donación, la mitad de las casas, explícitamente como feudo, lo que confirma que estos instrumentos eran un tipo de infeudaciones. También se recordaba la fidelidad del recipiendario, el cura Bernat, que de nuevo se hacía extensiva a quien trabajase las fincas. En esta ocasión, Ponç incluso se reservaba el derecho de aconsejar al beneficiario de la explotación sobre la elección de los trabajadores agrarios ${ }^{86}$.

En resumen, el poder condal dirigió el proceso feudalizador de Lleida y Tortosa, desplegando un programa innovador con estructuras gubernativas que aseguraron el equilibrio entre los conquistadores, y otras medidas que procuraron la continuidad de un modelo urbano que disponía de una agricultura próspera y mercantilizada. La asimilación de las estructuras andalusíes estuvo presente en todo el proceso, y la anterior centralidad del poder de la ciudad en el territorio tuvo como fenómenos paralelos la preminencia del poder señorial, ya fuese condal o de otros, que trababa dependencias personales de forma exhaustiva en toda la sociedad. La dejación de reclamación de beneficios en los inicios o de exigencias militares no significaron la fijación de una sociedad «menos feudal», sino que contribuyeron a consolidar una organización basada

$85 . . . e t$ ille laborator quam ibi miseretis sit mibi fideliter de mea tercia parte de ille quam ibi meseretis conveniat mibi fideliter dare meam terciam partem omni tempore sine engan...

86 ...et si dederis illos campos $V$ predicta ad laborandum ille laborator sit ibi ad consilium meum et non mitas illum ibi sine me et conveniat mibi dare et donet fideliter annuatim meum de quartum de omnibus, Diplomatari Tortosa, pp. 93-94 y Col.lecció Gardeny, pp. 151-153 (1154). En esta oportunidad la retención del dominio era de la cuarta parte, aunque en una explotación oscilaba entre la cuarta y la mitad, dependiendo de la contribución de Ponç a ciertas tareas. 
en dependencias personales y prestaciones económicas más operativa que en los otros ámbitos vistos.

\section{LA REDEFINICIÓN DE LOS DOMINIOS Y DE LAS PRESTACIONES ECONÓMICAS}

Las fórmulas de intervención señorial en la Cataluña Nueva fueron adaptándose a las condiciones impuestas por la incorporación de nuevos espacios y, especialmente, en los que se sometió a las poblaciones musulmanas. Además, algunos de los cambios de la formación políticosocial respondían a la necesidad de eliminar eventuales conflictos que pudiese generar la belicosa clase feudal. En este contexto, se produjo la reorganización de la aristocracia feudal y del mapa dominical, que tuvo una manifestación en el crecimiento patrimonial de grandes instituciones cenobíticas, como el Císter o las órdenes militares. Los fenómenos de redefinición socioecónomica incidieron en nuevas formulaciones de las relaciones interpersonales y de las exigencias de las prestaciones económicas.

El conde de Barcelona introdujo al Císter o a las órdenes militares para la consecución de ciertos objetivos, y por tanto a modo de extensión del poder condal, como en la comentada fundación de Poblet con la que neutralizó o mermó la eclosión del linaje Cervera en la región. En otro orden de cosas, concedió el dominio de Amposta a la orden del Hospital para implicarla en la defensa y control de un lugar estratégico, como sucedió con el Temple tras las conquistas, aunque otras razones poderosas derivadas de la unión con Aragón marcaron el impulso de las mencionadas organizaciones militares.

Una vez efectuadas las primeras donaciones importantes a las órdenes en la Cataluña Nueva, el mismo Ramón Berenguer IV y su hijo Alfonso el Casto culminaron el proceso de concesión de amplísimos patrimonios a templarios y hospitalarios. En este sentido, queremos destacar que las nuevas dotaciones a sendas instituciones borraron compromisos o donaciones anteriores, como se constata en los fenómenos de formación de las encomiendas de Miravet, Ulldecona, Amposta, Ascó y Horta, entre otras ${ }^{87}$. Así, el conde o sobre todo el rey mo-

87 En el dominio de Miravet, el conde había cedido a Galindo Belxit tierras en Benissanet (1148/9), y después formaría parte de la encomienda de Miravet, Col.lecció Gardeny, p. 108; Ascó había sido concedida al conde de Urgell, en la famosa convenientia de Lleida Codoin, IV, pp. 126-129, o incluso Amposta se había librado al conde de Pallars a fines del XI, Archivo de la Corona de Aragón o ACA, Ramón Berenguer III, carpeta 58, 51. Si bien en estos casos, las donaciones se produjeron antes de las conquistas, se constatan derechos del conde de Pallars en Amposta después de estas. Sin embargo, en Ulldecona existió un dominio con derechos importantes en los pastos de la comarca en manos de Arnau de Jaca antes de la donación al Hospital (1178), Diplomatari, pp. 235-6. Por tanto, ya no sólo se borraba un compromiso sino que el dominio se sobreponía a prerrogativas de otros cristianos. En Horta, el rey Alfonso había concedido a sus pobladores todo el término salvo el castillo en 1165, Cartas, pp. 184-5; y luego en 1177 libró el castillo al Temple desde donde se formó la encomienda, Col.lecció Gardeny, pp. 466-67. El documento de 1165 ha llegado a través del Cartulario de Gardeny, por lo que manifestamos ciertas reservas sobre la referencia a la retención del castillo por parte del monarca, que 
dificaron las primeras previsiones sobre la definición de los dominios, seguramente tras los resultados de las actuaciones señoriales iniciales y de la reelaboración de las relaciones con los institutos militares.

Este intervencionismo, en consonancia con el crecimiento de la autoridad condal o real, refleja dos hechos fundamentales como fueron la implicación decisiva de las órdenes militares en la consecución de la feudalización, y la recomposición de las entidades patrimoniales que respondía a la reorganización de la sociedad feudal más allá de la expansión de las órdenes religiosas. Por tanto, y pese a la idiosincrasia del poder condal, las políticas de Ramón Berenguer IV deben entenderse como resultado de las propias necesidades o dinámicas de la clase aristocrática feudal ${ }^{88}$. Además, es bien sabido que los regulares ofrecían estabilidad en todos los sentidos dadas sus particularidades, a las que las órdenes militares añadían su especificidad militar. Dicha función explica porqué se intensificó su actuación casi exclusiva en la defensa o sometimiento del amplio frente fronterizo de la Cataluña meridional y, en definitiva, las razones de la corrección de rumbo del conde o la corona respecto de unas previsiones anteriores que habían atribuido una menor presencia o participación en las propiedades a las órdenes militares ${ }^{89}$.

La dilatación patrimonial de los regulares respondía al impulso de la monarquía, a los donativos de la aristocracia feudal, y sobre todo a un programa expansivo extraordinario desarrollado por las órdenes en los ámbitos inmediatos a sus patrimonios o en otros alejados o complementarios. Las propiedades de los monasterios cistercienses de Poblet y de Santes Creus, salpicaban territorios apartados de sus cenobios, y se erigían en potencias señoriales con sistemas económicos diversificados y complejos, que eran diferentes a los característicos de las Marcas hasta esas fechas. El progreso patrimonial de los templarios fue igualmente espectacular mediante la incorporación de bienes a partir de un núcleo inicial como en Lleida, o de forma más amplia cuando redondearon su casi monopolio señorial en la Ribera del Ebro catalán al obtener el señorío regio de Tortosa y el distrito de

podría tratarse de una interpolación hecha por los templarios para legitimar la donación del 1177, que seguramente colisionó con los derechos de los habitantes del lugar.

${ }_{88}$ Precisamente J.M. Salrach advierte que en la segunda mitad del siglo XII la autoridad de los condes parece afianzarse, que valora como resultado de los éxitos políticomilitares y de las exigencias de reorganización de la clase feudal: «Prácticas judiciales, transformación social y crisis política en Cataluña» en Hispania, (Madrid) LVII/3 197 (1997), pp. 1009-1048/ 1039.

${ }^{89} \mathrm{La}$ función militar de las órdenes justifica su enorme implicación en los ámbitos conquistados e incluso en los que se pretendía ocupar. Sin abordar el tema, cabe destacar que templarios y hospitalarios obtuvieron la quinta y la décima parte de las tierras susceptibles de conquista en fechas relativamente tempranas, se les obsequió con beneficios de las parias, y se les encomendó fortificaciones estratégicas —incluso antes de su conquista-. Además se les confió el dominio de lugares donde subsistieron los reductos de población musulmana más importantes, como Miravet o Ascó, tuvieron cautivos empleados en sus reservas, y en el siglo XIII participaron activamente en la persecución de los cautivos fugitivos. Este conjunto de acciones se relaciona necesariamente con su capacidad militar. 
Ascó en $1182^{90}$. De forma semejante, los hospitalarios de Amposta añadieron propiedades en la punta de lanza de Cataluña, hasta convertirse prácticamente en los únicos señores del Montsià ${ }^{1}$. Las intervenciones de las órdenes militares se apoyaban en un sistema de capitalización temprano, que se nutrió de una extraordinaria recepción de bienes muebles, limosnas en dinero o rentas para atender a la obligación de consignar recursos a sus centros en Jerusalén y se tradujo en una enorme capacidad financiera para comprar o prestar ${ }^{92}$.

El Temple satisfizo cinco mil morabetinos al rey por los mencionados dominios de Tortosa y Ascó, siendo uno de los numerosos testimonios de la disponibilidad de sumas importantes de numerario. En el trato, Alfonso el Casto se reservó la mitad de las rentas en dichos lugares o de cuanto incorporasen a su patrimonio, con lo que en cierto modo recuperaba la antigua actitud señorial de reservarse una parte de los censos, abandonando la práctica de su padre en sentido contrario. Sin embargo, de las fórmulas clásicas de las convenientiae sólo quedaba la retención mencionada, ya que el rey transfería el dominio y se inhibía explícitamente de las acciones militares o de la exigencia de rentas arbitrarias.

En realidad, el monarca quería obtener rentas e incluso aprovecharse del momento de gran crecimiento del patrimonio templario, y por tanto coparticipar del auge o de la capacidad administrativa de la orden aunque supusiere la pérdida del señorío ${ }^{93}$. Las políticas «benefactoras» o de afirmación de la autoridad de Ramón Berenguer IV, orientadas a favorecer la feudalización en tierras conquistadas, no reportaban a la monarquía en esta época lo que necesitaba y por tanto persiguió rentabilizar su dominio aunque paradójicamente fuese perdiendo el control dominical. Esta preocupación se manifestó asimismo en la última definición del señorío de Tarragona en 1173 cuando el rey confirmó su vasallaje al arzobispo, si bien incrementó la participación en las rentas ${ }^{94}$.

Los dominios de las órdenes monásticas y militares crecieron gracias a una amplia actividad de compra o de obtención de donaciones votivas, aunque tras

90 Pagarolas, L.: op. cit., pp. 245-249.

${ }^{91} \mathrm{La}$ primera incorporación en el flanco más extremo y custodiando la frontera afectó a Ulldecona (1178), y el proceso se alargó en el tiempo afectando a la Aldea a inicios del XIII, y a la Rápita en 1260, que el rey Alfonso les había donado en 1171 pese a que era de Sant Cugat, aunque no se hizo efectiva.

${ }^{92}$ Las órdenes llevaron a cabo una gran cantidad de compras en este período o después y procuraron préstamos a la corona u otros. El envío de las responsiones en los primeros tiempos se conoce sólo indirectamente, aunque los estatutos del siglo XII definían los compromisos económicos de las tierras occidentales con el ámbito oriental cruzado.

93 La voluntad regia de beneficiarse del proceso de crecimiento patrimonial se refleja en la precisión que hacía el rey del mismo: eius fratres adquisierint donacione vel empcione vel pro eo belemosina vel alio...modo...medietatem mibi rentineo.

94 Para Tarragona, BlAnCH, J.: op. cit., pp. 106-108. La preocupación de obtener rentas en Tortosa se confirma en la imposición a la orden de un baiulo que le sería fideliter y que las cobraría y otro en Ascó, quienes obedecerían al rey en el tema de la mitad de sus derechos, fijando un control más o menos ajeno a la orden. 
esta fórmula se escondía una variedad de situaciones que no siempre surgían de la voluntad libre de los concedentes. En este sentido, algunas donationes pro anima solían ser el resultado de la necesidad económica del donante o de la presión que ejercía la institución hasta alcanzar el patrimonio que le interesaba. Las intervenciones de los templarios en Lleida y Tortosa demuestran que las «compras» o «donaciones» forzaron la transferencia de las propiedades por parte de señores menores establecidos tras la conquista, en el mejor de los casos a cambio de un pago compensatorio, o de tierras mediante una permuta, o bien conservando en ocasiones la antigua propiedad como tenencia. En las Marcas se produjeron fenómenos parecidos, pero en un clima de mayor resistencia por parte de los afectados.

El fenómeno de concentración patrimonial conducido por las mencionadas instituciones comportó una inevitable reorganización social, que se constata en el cambio de la condición de propietarios a tenientes. En muchas donaciones votivas donde el titular mantenía derechos de explotación en su antiguo predio, sólo era de forma transicional, puesto que dichas prerrogativas no alcanzaban a los descendientes como le sucedió a Berenguer Piñol. Este mecanismo restrictivo debía servir indirectamente para evitar posibles reclamaciones de familiares ${ }^{95}$. De todos modos, el cambio de propietario a teniente no entrañaba necesariamente que el afectado se dedicase a la explotación de la tierra sino tal vez a su gestión, como podría pensarse de personas de cierto nivel social como Pere Rajadell ${ }^{96}$. En otro tipo de documentos, se constata que algunos tenientes

${ }_{95}$ Berenguer Piñol y su familia se desprendieron de su huerto en Benifallet, que trabajaría Berenguer hasta su muerte y sujeto a un censo anual que indicaba la nueva dependencia. La familia quedaba vinculada a la fraternidad de Poblet, y por tanto podía disfrutar de cierta protección o recursos, aunque temporalmente. De la naturaleza asimétrica del pacto habla la compensación de cuatro morabetinos consignados a Piñol, Diplomatari, pp. 148-9 (1155) y pp. 153-4 (1155/1170) respectivamente. A su muerte otro teniente, Alcaleto, disfrutaba del huerto, que muestra como se había apartado de la explotación de la tenencia a la familia según lo previsto, ibidem, pp. 306-7. Otras donaciones convirtieron al propietario en teniente como las efectuadas por Guillem Aimeric, quien libró al monasterio de Poblet un huerto en Tortosa —obtenido del conde-, y lo tendría en vida sujeto al canon de doce dineros, o la de Guillem Gonter, quien en otra donatio post obitum transfirió una viña, reservándose la mitad en vida, Diplomatari, pp. 142 y 143 (1154). También en otros ámbitos distintos como en la Conca o Lleida se encuentran ejemplos parecidos. En Barberà, el proceso de expansión del Temple atrapó a Ramón Aguiló, quien pagaría doce dineros para: et ipsos denarios superios scriptos dono in vita propter hoc ut illi recipiant michi in suis beneficis. Aunque la fórmula documental era aparentemente una donación por la remisión de los pecados, el donante advertía que ponía fin para siempre a la discordia mantenida con el Temple, y por tanto a un proceso de pugna por la propiedad, Col.lecció, pp. 139-140. Sin embargo, en las regiones feudalizadas antes de mediados del XII, algunas fórmulas de posesión del bien cedido guardaban similitud con las condiciones típicas de subinfeudación más que con las cercanas a un establecimiento sujeto a un canon agrario. Así en la donación por la remisión de los pecados efectuada por Berenguer Arnau de Anglesola de un campo en Barbens, se retenían la cuarta parte del cereal, diezmos y primicias hasta la muerte de su hijo, y además obtenían a cambio 100 morabetinos, Diplomatari, pp. 386-387 (1175).

${ }_{96}$ Pere Rajadell donó un huerto en Tortosa al monasterio de Poblet, y comprometió el pago 
disponían de campesinos para el trabajo agrario e incluso ocasionalmente se diferenciaba el pago en concepto de censo efectuado por el teniente de las rentas agrarias propiamente dichas, obtenidas y vinculadas a los labriegos, aunque el compromiso de satisfacción solía recaer en el teniente ${ }^{97}$.

En los procesos de pérdida de titularidad por donación, el censo se manifestaba como la clave de acceso a una nueva condición de dependencia originada por la disponibilidad de la tierra, ya fuese vitalicia o indeterminada. Al menos en una ocasión, la nueva vinculación personal alcanzada para disponer de la tenencia se manifestó con un compromiso de fidelidad público mediante la tradicional fórmula de la inmixtio manum. De este modo, la situación se homologaba al homenaje, cuando en realidad el nuevo dependiente era sólo un receptor de tenencia equiparable al beneficiario de un establiment ${ }^{98}$. El ejemplo muestra que el homenaje, símbolo de la fidelidad vasallática, se iba trasladando a otros niveles sociales no privilegiados, de la misma manera que las nuevas fórmulas contractuales se asemejaban a los antiguos pactos feudovasalláticos y que algunos señores perdían tal condición, pasando a formar parte de una nueva dependencia no vasallática.

Tal vez sea una obviedad indicar que la pérdida de los derechos de la propiedad significaba un trascendente cambio socioeconómico para los afectados, aunque las necesidades económicas forzaron algunas donaciones y en estas ocasiones las contrapartidas proporcionaron alivio temporal a los donantes ${ }^{99}$. En

de un censo de doce dineros, Diplomatari, p. 147 (1155). El mismo día hizo otra donación para la remisión de sus pecados a la sede de Tortosa, aunque si bien indicaba et tenebo hec predicta per predictam ecclesiam quamdiu vixero no se fijaba el censo, Diplomatari Tortosa, pp. 104-105. Pere Rajadell había sido beneficiado por el conde con varios bienes, que nos aproximan a una persona que tuvo una posición económica notable, a pesar de estas pérdidas de patrimonio.

${ }_{97}$ En la concesión de dos parcelas de tierra a Raimon y Joan de Coscol se distinguía el censo de la renta agraria, y se contemplaba la posibilidad que no las trabajasen ...per duos kafitos de blado de censu, quos vos et vestri vel qui pro vobis habuerit donetis nobis et nostris in unoquoque anno...annuatim, terciam partem de frumento et terciam partem ordi et terciam partem de avena, Col.lecció Gardeny, pp. 378-7 (1174). Elementos dispersos descubren a Raimon de Coscoll como una persona situada en la elite del campesinado, quien en 1165 vendía una parte de su huerto junto a las murallas de Lleida, Diplomatari, pp. 214-5; o más tarde aparecía junto a otros como explotador de otras parcelas, Col.lecció Gardeny, pp. 368-9, y administrador de un molino también del Temple, pp. 433-434 (1175). Precisamente su posición social explicaría su condición de intermediario en el establecimiento mencionado.

${ }^{98}$ La transferencia de una propiedad al obispado de Tortosa significó al donante mantenerse como beneficiario de la tenencia de la tierra sujeto a un censo y hasta su muerte o de su mujer, y constaba como donación y venta. La compensación de un pago por la venta demuestra que la transacción tenía un móvil económico, más allá del meramente espiritual, y el concedente manifestó su vinculación: ...pro hac terra Martinus fecit hominium mibi Gaufredo iuncits manibus missis inter manus meas promitens fidelitatem..., Diplomatari Tortosa, pp. 108-9 (1155).

99 Berenguer Calders hizo una donación votiva al Temple a cambio de 300 sueldos procedentes de las limosnas, y por tanto la hizo forzado o condicionado por la necesidad. Además mantenía la tenencia del mansum mediante la satisfacción de un censo: et dono vobis de tenedone 
alguna oportunidad, la donación votiva de una heredad se compensó con unas pocas tierras y otros recursos, como los que obtuvo Andregot para sustraendam nostram inopiam y, por tanto, los resarcimientos se destinaban expresamente a evitar la pobreza de quienes perdían lo que hasta entonces había sido una fuente de recursos ${ }^{100}$.

Los procesos de cambio social fueron diversos, y algunas fórmulas procuraron sustento y protección en el seno de la misma orden, como sucedía con quienes ingresaron como monjes y conversos en los monasterios o confrares y donados en el Temple. En estos casos, la entrada al cenobio era la consecuencia de la entrega de su propiedad, como se constata en un número amplio de entradas a Poblet como monjes o oblatos en la época de máxima actividad de captación de patrimonios. Como se ha visto algunos señores importantes de la comarca, como los conocidos Pere de Queralt o Ramón Boixadors y miembros de la familia Cervera, se incorporaron a la clausura, pero también se integraron otras personas con pertenencias menores, quienes a menudo lo hacían como conversos.

En esta transición de propietario a teniente resulta muy significativa la conservación de los derechos de algún converso como teniente de su antigua propiedad. Además algunos donados obtuvieron pagos compensatorios, aunque siempre se resolvían como soluciones transitorias destinadas sólo a los donantes $^{101}$. La heterogeneidad de estas situaciones queda bien reflejada en la forma

parilium gallinarum in predictum mansum. Finalmente, y para mantener un cierto nivel de vida se entregó a la orden, al parecer como confrare, Col.lecció Gardeny, pp. 344-45, (1170). En más ocasiones la compensación económica se pagaba de las limosnas y pensamos que esta especificación tenía ciertas connotaciones para el beneficiado y la institución benefactora, como sucedió en la donatio post obitum de Ramon de Castellnou al Temple en un lugar cercano al Francolí, donde decía et proper hoc recipio de elemosinis Domus Milicie Templi IX solidos...tali condicione ut ego teneam hec pecia terre de mea vita, Col.lecció, p. 155 (1175). Asimismo Gombau Oluja obtuvo cien sueldos de las limosnas tras ceder su dominio en un mansum a la encomienda de Barberà, aunque se reservaba el diezmo de por vida de modo excepcional, Col.lecció, pp. 197-198.

${ }^{100}$ Col.lecció Gardeny, pp. 168-9 (1156); y en otra parte se expresa ...Quem vero pauperitas nos cogit et necessaria non sufficiunt, accipimus a fratribus Templi... Las necesidades o dificultades también debieron forzar la donación de los derechos sobre una parte del diezmo de Arnau de Anglesola y familia a Poblet, y a cambio obtuvieron dos cahices de avena y dos de trigo, valorados en trescientos sueldos que devolverían si Deus negocia nostra ad prosperitatem perducere..., Diplomatari, pp. 385-6.

${ }^{101}$ Guillem de Cervera y su mujer se entregaron junto su hacienda de Cérvoles en 1163 y Ramon Boixadors en 1182 con bienes, aunque antes había empeñado tierras al monasterio, Diplomatari, pp. 200-1 y Cartulari de Poblet, p. 83, respectivamente. Personajes más modestos se libraron a Poblet como Burd de Ribera con su mansum de Vimbodí (1184); Joan Martí con su honor para ser converso (1178) y también como conversos Ferrer con su honor de Vimbodí (1186) o Bernat Jozbet (1187), Cartulari de Poblet, pp. 53-54; 70; 76; 45-6 respectivamente. Bernat Corcard fue recibido como converso, pero mantuvo la condición de teniente a juzgar por el compromiso de satisfacer un censo, quien además renunciaba a los derechos que su abuelo había transferido, tal vez abandonando presuntas reclamaciones, Cartulari de Poblet, pp. 43-44 (1187). También en la encomienda templaria de Barberà, se vinculó Ramon Guerau y se comprometió a la satisfacción de 
particular en que Arnau de Bordells ingresó en Poblet en 1163. Este satisfaría un pago anual y las décimas de todos sus bienes mientras no se vinculase a la clausura a cambio de protección o defensa por parte del monasterio, extremo que no se contemplaba en las restantes incorporaciones al cenobio ${ }^{102}$. En la encomienda templaria de Lleida de Gardeny también se descubre la relación entre el período de crecimiento patrimonial y la época la integración de un grupo de la pequeña y mediana nobleza en régimen de confraternitas, que afectó a un número importante de más de noventa entre donados y confrares entre 1176 y $1204^{103}$.

A la luz de estas transformaciones sociales derivadas de la reorganización de la aristocracia y de las propiedades dominicales, cabe recordar que fenómenos semejantes afectaron al encaje de ciertos elementos privilegiados de la población andalusí sometida, aunque con una trascendencia muy distinta. Como se ha visto, algunos propietarios musulmanes fueron sujetos al régimen de tenencia mediante la «exariquia», mientras que unos pocos todavía subsistieron como tales algunos años y algún cargo significado permaneció al menos un par de décadas. Por tanto, algunas de las fórmulas de sometimiento estratégico de los andalusíes se aplicaron de forma semejante cuando se subyugó a los propietarios cristianos mermados por una economía señorial renovada. Así, las medidas adoptadas con ciertas elites musulmanas surgían de las tradiciones de organización de la sociedad feudal, y se manifestaron en los desarrollos de ésta en los ámbitos de expansión, sin que con este argumento se pueda minimizar el impacto destructor de los conquistadores en el mundo andalusí.

un censo, aunque no determinaba si se acogería a la clausura o sólo sería enterrado junto a los freires, Col.lecció, pp. 207-209 (1186). A veces, el ingreso en el monasterio era una compensación, garantía o protección ante la nueva y peor condición socioeconómica, como sucedió a Pere Gallard (1198). Este se había visto obligado a conceder un alodio por una deuda contraída con Poblet a cuenta de un censo, obteniendo a cambio dos cantidades de trigo — que parecen delatar una situación de necesidad - y la posibilidad de ingresar en el monasterio, Cartulari de Poblet, p. 50. Podría tratarse del mismo Gallard que, en 1185, se había entregado al cenobio con la mitad de sus bienes, y quedaba vinculado por el pago de un censo, es decir como teniente, Cartulari de Poblet, p. 52. De las vicisitudes de los legos, da cuenta Carbonell, quien dio bienes y derechos jurisdiccionales a Poblet a cambio de 50 sueldos, que debería restituir o de lo contrario daría otra propiedad. Aunque se había entregado, quedaba en el aire si lo haría en vida o sólo para enterrarse, ibidem, p. 79 (1178). La mayor parte de estas vinculaciones a Poblet como conversos afectaban a propietarios de Vímbodi y tiene una explicación coyuntural que no nos aventuramos a ofrecer.

102 Diplomatari, p. 200. La noticia se contextualiza en las características de las incorporaciones tempranas como una serie de ventajas para los donados en el período de arranque de la institución. También existe algún caso en que los familiares obtuvieron parte del patrimonio, como parece sucedió con Gaufredo Anglés, quien cedió todos sus propiedades en la región de Tortosa al monasterio de Santes Creus, y se entregó como monje, testificando el acto un tal Joan Anglés (1173). Joan, censatario de otros bienes del monasterio obtuvo una heredad de Gaufredo (1187), LBSC, pp. 174-5; 176; y 286. No se ha podido constatar el más que probable parentesco, pero sin duda era una persona allegada.

103 SANS, J.M.: Els templers catalans. De la rosa a la creu, Lleida, 1996, desde p. 329 y según Bertran, P.: «Gardeny: Els templers de Lleida» en Lleida, la ciutat dels dos turons, Lleida, 1992. 
El proceso de absorción de propiedades por parte de los grandes monasterios generó distintas formas de resistencia, consecuencia de la imposición que ejercieron, directa o indirectamente, a la hora de incrementar sus patrimonios. Algunas disputas terminaron en los tribunales, como las reclamaciones que Alegret de Altafulla presentó a la curia de Tortosa por la pérdida de sus tierras a manos de los templarios y, aunque la «concordia» de 1179 comportó su renuncia, fue compensado con otras tierras lo que reflejaba que su oposición estaba justificada ${ }^{104}$.

A pesar de esto, el progreso en la redefinición de los dominios causó tensiones de mayor envergadura y más conflictos en la región de las Marcas, donde los linajes estaban mejor enraizados en el territorio y las relaciones sociales fijadas. Así sucedió en los procesos de formación de las encomiendas de Corbins y de Barberà, para citar dos ejemplos significativos o en la consolidación de Poblet $^{105}$. Corbins había quedado vinculado al Temple en la famosa solución del testamento del rey aragonés impuesta por Ramón Berenguer IV en 1143 quien, y pese a ello, infeudó el lugar a Berenguer de Anglesola pocos años después ${ }^{106}$. Desde la segunda mitad de los cincuenta y en la década de los sesenta algunas compras efectuadas por los templarios les dieron entrada en algunos sitios del ámbito de Corbins, incluso alguna la hicieron al poderoso linaje de los Anglesola, con quien y, pese a ésta, mantuvieron un conflicto ${ }^{107}$. Las querimo-

${ }^{104}$ Pagarolas, L.: op. cit., pp. 238-9. El rey había donado a los templarios bienes que pertenecían a Alegret y a otro, Oller, cuya propiedad también terminó siendo de los freires, ibidem, pp. 232-235.

${ }^{105}$ Hemos dado cuenta de las disputas de Poblet con los hombres de Vimbodí, y otros testimonios muestran los conflictos derivados del crecimiento del monasterio, llegándose a producir querimonias por cuestiones tan concretas como los olivares de una tierra, que en teoría había obtenido el cenobio por donación o venta. La situación no debía ser claramente favorable a Poblet, puesto que hizo un discreto donativo para zanjar las exigencias de quien tenía que haber sido la heredera, Diplomatari, p. 401, (1175).

106 ACA, Orm, Cartulario de Gardeny, y desde ahora n. 193, f. 55r-v (1147 o 1148); se trataba de una convenientia según la modalidad más clásica de infeudación de dos tercios, y retención del tercero para el donante, que era Ramón Berenguer IV. Así, ignoraba lo que el mismo había comprometido a los templarios como pasó otras veces. De todas formas en la compra de tierras en el lugar de Corbins efectuada por el Temple, Bernat de Anglesola se refería a la procedencia de lo que vendía sicut pater meus Arnallus Berengarii melius acaptavit et aprisiavit, Col.lecció Gardeny, pp. 214-216 (1161). Por tanto una vez más el conde fijaba el pacto, si es auténtico, con el linaje para alcanzar la vinculación vasallática de quien ya se había establecido en el lugar anteriormente, y de nuevo en vísperas del ataque a Lleida.

107 Arnau de Soler y Ermessenda efectuaron una de las primeras ventas a los templarios, quienes tenían el honor per aprisione, y reitera el fenómeno de ocupación señorial anterior a las intervenciones del conde o de los templarios, ACA, ORM, n. 193, f. 57v (1157); sin embargo, la tierra afrontaba con unas viñas quem teneo per eos. Así, los donadores eran tenientes de otras tierras del Temple, y esta dependencia o quizás ciertas dificultades, que se deducen de la obtención de una parte del pago en cereal, forzó o animó la venta. Ponç de Santafe también vendió un alodio en Corbins por una suma importante, que tenía de parte de los Anglesola, Col.lecció Gardeny, pp. 219-20 (1162). 
niae se zanjaron con la renuncia de Arnau de Anglesola a todo cuanto tenía en el castro de Corbins y de Palau ${ }^{108}$.

Las resistencias al fenómeno de redefinición del mapa señorial en beneficio de las grandes instituciones regulares en ámbitos de las Marcas como en la Conca de Barberà o en las cercanías de Lleida, se relaciona con un proceso de ocupación señorial dilatado en el tiempo, y que en la época abordada se reconoce en las indicaciones a espacios aprisionados. Este término, tal y como lo analizó E. Hinojosa, significa la adquisición de tierra mediante ocupación y cultivo que culminaba con el derecho de aprissio concedido por el conde o representante. Además, la propiedad sobre estas tierras se transmitía hereditariamente, y podía tener arrendatarios o patrocinados ${ }^{109}$. Como es sabido, este proceso caracterizó la colonización de la Cataluña Vieja y también los espacios de las Marcas durante una larga época entre los siglos IX y XII ${ }^{110}$.

Siguiendo el planteamiento de E. Hinojosa y L. García de Valdeavellano, la señorialización era consecuente o incluso inherente al proceso, que reconocemos en las regiones de las Marcas a mediados del XII y es sinónimo de ocupación señorial, aunque sus orígenes hubiesen sido la colonización campesina. Así cuando se indicaba la condición de tierra aprisionada en las transferencias de propiedad se aludía a la legitimidad de quienes en ese momento eran donadores de sus bienes y, en definitiva, constituía una garantía para los nuevos titulares.

En otro orden de cosas, algunas referencias a «aprisiones» en las regiones de la expansión o en sus inmediaciones, resultan interesantes porque muestran cómo con posterioridad al fenómeno de aprehensión o señorialización según el caso, se habían sometido a un señor o a un dominio más importante. Así, Pere

108 ACA, ORM, n.193, f. 72v y 73r: ...difinimus omnias querimonias...

109 HinOJOSA, E., op. cit., pp. 62-63.

110 HinojosA, E., ibidem, p. 66. En la misma línea interpretativa García de Valdeavellano, L., indica que la ocupación originaba un derecho real transmisible por herencia, aunque valora que en Cataluña el proceso fue llevado a cabo principalmente por magnates e institutos eclesiásticos. Según el autor esta modalidad fue substituida por la concesión de cartas de población tras las conquistas de Tortosa y Lleida: Curso de Historia de las Instituciones españolas, Madrid, 1984, p. 243. Efectivamente, los testimonios de esto modo de captación de tierras en las regiones más avanzadas del país disminuyen, aunque no desaparecen, y a nuestro entender no son equiparables a las cartas de población. Otros análisis consideran el fenómeno más vinculado o únicamente relacionado con las ocupaciones campesinas como FONT, J.M.: op. cit., II, 1983, pp. 79, 80 y 458, quien lo ha relacionado de forma directa con la explotación de yermos y otras modalidades de ocupación. Cercano a esta valoración, BONNASSIE, P., op. cit., II, p. 44 señalaba que la aprissio conducía al alodio y contrarrestaba las pérdidas por «amputación» que sufría la pequeña propiedad campesina, aunque refiriéndose a la Cataluña Vieja y hasta mediados del XI. También SALRACH, J.: El procés de feudalització, ss.III-XII, Barcelona, 1987, pp.188-193 y 209 vincula las aprisiones con colonizaciones campesinas que desarrollaban la pequeña propiedad en la Cataluña Vieja anterior al 1000. El tipo de propiedad descrito por E. Hinojosa o de L. G. de Valdeavellano se identifica con la señorial —aunque no exclusivamente-, mientras que el segundo grupo de autores reconoce un modo de iniciativas llevadas a cabo por el campesinado, que además se califica de libre. 
de Santesteve y su esposa Ermessenda, donadores del castillo de Ollers en 1164 , indicaban que les pertenecía porque ella lo tenía por accaptamentum y por aprissione de sus padres. Luego Ermessenda agregaba que lo tenía por Bernat de Santa Coloma. Esto indicaría que sus ascendientes ocuparon el término castral o castillo, y por tanto como señores o ejerciendo un papel similar, y que luego, o quizás paralelamente, había caído bajo la dependencia de un señor ${ }^{111}$. En la venta efectuada por Cocard, su mujer y Guillem Otgers de dos tercios de un molino en el río Anguera a Guillem Montfalcó se deduce una situación análoga cuando los vendedores afirman tenerlo por aprisio suya o población y por donación de Guillem Montfalcó ${ }^{112}$.

Para valorar o comprender adecuadamente las citadas aprisiones, cabe conocer la condición socioeconómica de sus agentes, que se muestra heterogénea, ya que en Ollers eran personas acomodadas, o al menos privilegiadas, y algunas ventas en Barberà afectaron a tenencias campesinas, fruto de la colonización ${ }^{113}$. Pese a la disparidad de situaciones socioeconómicas que encubría el término aprehender, se usó como sinónimo de colonización campesina y a su vez de sujeción al dominio de uno u otro señor feudal ${ }^{114}$. Por tanto, mantenía el senti-

111 Col.lecció, pp. 132-133, los concedentes ejercían una particular retención de dominio, que aproximaba la donación a una infeudación, et retenimus in ipso castro potestatem et ominaticum et meliorem mansum qui ibi fuerit in dominio. Cabe precisar que el verbo accaptare, común a otros documentos, traducido como «obtener de» expresaba la dependencia con Bernat de Santa Coloma, quien tenía un dominio en Ollers, Col.lecció, p.131. Luego en 1180 Arnau Verdú, que había recibido la mencionada donación y Pere Santesteve, el donador, transfirieron sus derechos en el castrum de Olers al comendador del Temple de Barberà, quienes aseguraban et advenit nobis per populacionem de aviorum nostrorum et per aviorum nostrorum voces..., que se aproximaría al sentido de la ocupación o aprissio, pero sin embargo no había referencia alguna al señor del lugar Bernat de Santa Coloma, Col.lecció, pp. 181-182; quien sí constaba como tal en otra transferencia de los derechos de Pere Lotgers en Ollers a favor de los templarios, Col.lecció pp. 185-186 (1181). Además este ejemplo de Ollers ilustra la compleja trama de jurisdicciones que se había desarrollado al ritmo de la intensificación de la ocupación señorial.

112 Así se expresa et advenit nobis illum molendinum per nostram aprisionem et populacionem et per donum vestrum, Col.lecció, pp. 205-206. La indicación a la doble procedencia muestra como posiblemente Guillem de Montfalcó intervino para convertirse en el señor después de que lo explotasen quiénes lo aprehendieron o construyeron, y que quizás las dificultades para conseguir dicho control culminaron en el pago de 100 sueldos. Sería extraño pensar que primero les donó, luego lo ocuparon y finalmente pagó. El nuevo señor no tardó en librarlo al Temple, con una breve mención a que los molinos «fueron de los antedichos», Col.lecció, pp. 206-207. Otro testimonio de 1168 refiere la donación de Guillem Pere de Guàrdia e hijos a su hija Laureta de un manso que Pere Arnau de Gavar e hijos habían aprehendido en el término castral de Barberà, Col.lecció, pp.135-136. Todo y que este es menos explícito que el anterior, los titulares no eran quienes lo habían obtenido por aprissio, y reitera la posibilidad de que una primera propiedad — fruto de la apropiaciónhubiese caído bajo otra dependencia dominical.

113 Sirva de ejemplo la venta de una parcela al Temple, Col.lecció, p.165-166 (1176) o la antes mencionada de Arnau Soler y esposa al Temple de la tenencia aprisionada, ACA, ORM, n. 193, p. 57v.

${ }^{114}$ El concedente de una yugada en el término de Verdú refería que uno de los límites ab una parte in alodio quod non est aprisatum, es decir explotada o colonizada, e impuso al beneficiario el 
do inicial de derechos adquiridos por ocupación, pero que, lejos de un reconocimiento por parte del poder soberano o condal, resultaron de iniciativas particulares que, en determinados casos y quizás por dicha condición original, fueron integrados en otros dominios o jurisdicciones ${ }^{115}$.

El fenómeno expansivo contribuyó a la definición de un sistema de prestaciones distinto al que se había desarrollado en los ámbitos de las Marcas, e incluso en el de Tarragona en los primeros tiempos, aunque también en estas regiones y evidentemente en las conquistadas asomaron los cambios respecto del antiguo y complejo modelo de satisfacción de rentas ${ }^{116}$. Se desarrolló otro sistema, más simplificado o racionalizado, que respondía a las nuevas condiciones creadas por la expansión, por el crecimiento económico y la economía mercantil, las migraciones u otros elementos. Uno de los aspectos indicativos de la naturaleza del cambio, se descubre en las manifestaciones señoriales de abandono de la exigencia de rentas por la fuerza o incluso en la progresiva relajación de su demanda, aunque estas imposiciones arbitrarias estuvieron vigentes al menos hasta el siglo XIII en los tres ámbitos regionales estudiados ${ }^{117}$.

Las renuncias de los señores a las rentas arbitrarias debieron dar respuesta a las reivindicaciones del campesinado, al peligro real de que su resistencia se convirtiese en migración y sin duda, a las posibilidades de obtener rentas suficientes o abundantes mediante otros mecanismos no contestados ${ }^{118}$. Hemos

mismo servicio que a otros tenientes sicut alii aprisatores facient, Cartas, pp. 154-155 (1155). Los señores feudales que se hicieron con el control de un ámbito territorial consideraron que lo habían aprehendido, como Ramon de Cervera cuando se refería a su dominio en la Espluga y otros et advenit ad nos... suprascripta per aprisione aut per ullasque voces, Cartas, pp. 145-146 (1152).

${ }^{115}$ No discutimos la explicación de E. Hinojosa, puesto que abordamos una época y geografía distintas.

116 Pensamos que resulta muy complicado establecer lo que satisfacían los campesinos en términos absolutos, por lo que se ha abordado en términos relativos, aproximándonos al conocimiento de las prestaciones económicas. Estas son fundamentales para intuir la situación del campesinado, junto a la condición jurídica según FeLIU, G.: «La pagesia catalana abans de la feudalització» en AEM (Barcelona) 26/1 (1996), pp. 19-41/25. Sin embargo, en los ámbitos y cronologías aquí estudiados la situación jurídica del payés pierde importancia y queda desplazada por las relaciones personales de dependencia.

117 Cabe destacar, y sólo a título indicativo, que las rentas arbitrarias se cobraron en Tarragona hasta el 1269; en la Guardia dels Prats en el XIII según ha visto P. Freedman, en Ulldecona en 1243 o en Amposta en 1281. A propósito de las rentas o métodos arbitrarios, Th. Bisson sostiene que se estaban generalizando en los distintos señoríos de Cataluña en el siglo XII, como reflejan las quejas consignadas en los memoriales de agravios, op. cit., p. 141. Sin poder ni querer demostrar lo contrario, los mencionados memoriales y las medidas en su contra emprendidas por la monarquía respondían al clima creciente de oposición, y a su vez significaba la admisión por parte de elementos de la clase dominante de la reacción social. Así, tanto si aceptamos su generalización, o el inicio de su disminución en estas fechas, se produjo una respuesta señorial a la resistencia que ocasionaban, que preludiaba su desaparición.

${ }_{118}$ A propósito de las posibles migraciones campesinas, un memorial de agravios recogía que los habitantes de Cabra - Camp de Tarragona - sufrieron tal opresión en la exigencia de las forces, toltes $i$ quests por parte de Berenguer de Clariana y su séquito que abandonaron el lugar, como sucedió en Argençola, BISSON, T.: op. cit., pp. 23-25. 
relacionado estas concesiones señoriales con la también progresiva desaparición de la exigencia de huestes y cabalgadas en las vinculaciones aristocráticas de la misma época ${ }^{119}$. Pese a tratarse de cosas bien diferentes, tenían en común la violencia feudal, que era un elemento destructor de los equilibrios sociales y ya no era un mecanismo útil o necesario para el ejercicio del poder después de la culminación las grandes conquistas. Las palabras del rey Alfonso en la transferencia al Temple de su parte de Tortosa resultan muy reveladoras puesto que en una sólo locución renunciaba a unas u otras formas de violencia: non habeam nec faciam...quistiam, neque toltam, neque forzam neque ost neque cavalgadam ${ }^{120}$. En cambio según lo visto, el monarca afianzaba su situación como beneficiario de rentas en el mismo acto.

De forma temprana en la carta de franquicia de Tarragona de 1149, los señores se comprometían a que ningún hombre fuese sometido a districtus - coerción acompañada a la justicia, forcia ni exactio —exigencia por la fuerza-. Poco después, al manifiestarse el conflicto entre ellos, el arzobispo lanzó múltiples acusaciones sobre la violencia ejercida por su vasallo Robert Bordet, como en la Selva y, quizás por eso, el prelado renunció a las rentas por la fuerza y a los malos usos en la carta de población del lugar ${ }^{121}$. Buena parte de estas renuncias se registraron en los instrumentos poblacionales, y teniendo en cuenta el tipo de fuente cabe interpretar que era una declaración de intenciones con finalidad propagandística, aunque al fin y al cabo respondía a un proceso de larga duración marcado por la negociación ${ }^{122}$. Precisamente los

119 Ya en fechas más avanzadas, y por tanto en otro contexto histórico, los señores liberaron a los campesinos tenientes de prestaciones de hueste y cabalgada, como sucedió en Villalba dels Arcs en 1223 por 15 años, o en Fontanet en Lleida en 1226. Como ha observado certeramente A. J. Forey, estas concesiones u otras procuraban que las tierras se mantuviesen en explotación, lo que confirmaría el rechazo a las exigencias militares o a las arbitrarias, también franqueadas en la carta de Villalba: The Templars in the Corona de Aragón, Oxford, 1973, pp. 203-204. Retomando la cronología estudiada, conviene indicar que la brusca renuncia a las exigencias militares en el marco de las relaciones de dependencia, no debe confundirse con la desaparición de compromisos militares o pseudomilitares. Así, por ejemplo, los vendedores de tierras al Temple en Tortosa se comprometían en algún sentido a actividades defensivas: et nos gariremus et defendemus...ab omni bomini, PAgAROlas, L.: op. cit., pp. 177 (1155) o convenimus vobis eam vineam garire et defendere ex omnibus personis extra forciam senioribus terre, ibidem, p. 176-7 (1153); y otros semejantes: ibidem, pp. 179 (1156), 183 (1157), 188 (1162). El conjunto documental es un tanto extraño, puesto que los vendedores parecen todavía implicados en la defensa de su antigua propiedad y, por tanto, todavía vinculados a la misma, pese a que no se exigían prestaciones económicas que les relacionase con su explotación. Podría tratarse de una fórmula orientada a asegurar la corrección de la transacción, pero aún así, el léxico era evidentemente beligerante.

${ }^{120}$ Las referencias más comunes a rentas por la fuerza son questia, tolta y forza, y cabe añadir la mención genérica a las tomadas por $v i$, y a intervenciones violentas como districtus. Véase BONNASSIE, P.: Cataluña, p. 268 y ss., que designa como piratería señorial o SALRACH, J.M.: «La renta», p. 67.

${ }_{121}$ Cartas, pp. 182-3; sine ullo malo usatico et sine ullo censo seu ulla vi et questia (1164).

122 Como testimonio de la renuncia señorial a la percepción de rentas arbitrarias sirva la carta de población de Agramunt concedida por el conde de Urgell, aunque a su vez perdonó la lezda, los usaticii 
pactos o el pragmatismo explican la regularización de algunas exacciones $\operatorname{arbitrarias}^{123}$.

Pese a los posibles avances hacia la supresión o remodelación de las rentas arbitrarias, éstas seguían constituyendo una entrada más, sin tratamiento excepcional, cuya percepción se empeñaba o arrendaba como las demás, y se enumeraban entre las jurisdiccionales de un dominio ${ }^{124}$. Su incipiente decadencia se produjo dentro del proceso de transformación de las rentas jurisdiccionales, cuando se afianzaron algunas como las de monopolios señoriales, mientras se redujo la variedad de las relacionadas con el ejercicio de la justicia, importantes en los prolegómenos de la expansión ${ }^{125}$. De forma paralela y en relación con estos cambios, la negociación y sobre todo la redefinición de las prestacio-

y la intestia, Cartas, pp. 176-178 (1163); o la concesión de un alodio en Montblanquet por parte de Ramon de Cervera donde se comprometía non fazemus ibi tolta nec forza, Cartas, pp. 187-188 (1166). Sin embargo, Ramon estaba enzarzado en una disputa por el reparto de las cuestias en las inmediaciones del lugar, y aunque esto no cuestiona necesariamente su cumplimiento, se constata el cobro de las rentas eximidas en lugares próximos en 1174, Col.lecció, p. 152. En una ocasión, este señor alcanzó un pacto con el beneficiario de un alodio por el que le redimía de opera nec quista neque tragi nisi decima et primitia, que refleja el debate sobre las exigencias señoriales, Diplomatari, pp. 177-178 (1160).

${ }^{123}$ La conversión de exigencias arbitrarias en un canon se refleja en una previsión señorial que reconocía a su teniente: et precipio ut Guillelmus Ninot de Munturgul non faciant questa nisi I migera de blad, Col.lecció, p. 154 (1175). Las cuestias y otros derechos en Albió se habían convertido en un pago ...unumquemque annum $L$ migeras inter ordeum et formentum et avena: $X X$ de ordeo et $X X$ de forment et $X$ de avena, Col.lecció, pp. 186-7, (1181).

${ }^{124}$ En la concesión de la mitad de las rentas del castillo de Horta a Pere de Subirats por parte de los Montcada en 1167 se indicaban las arbitrarias entre las jurisdiccionales: de iusticiis, de chestiis, de forciis, de invencionibus et quod habeas stacamentos. Se pedía a Pere que fuese solidus...in exercitus et in cavalcatis et in curia et in placitis, Col.lecció Gardeny, p. 280. Por tanto, el reparto y las condiciones seguían el modelo de las convenientiae, que nos muestra la continuidad de las fórmulas clásicas incluso en las tierras más extremas del país. Entre la retahíla de rentas percibidas en los mansi que Guillem de Bergadà transfirió al Temple las exigencias arbitrarias figuran con las de jurisdicción: districtis et mandamentis, placitiis, forciis, toltis, paschuis, silvis, garricis, Col.lecció, pp. 194-5 (1182).

125 Los monopolios aparecen en las retenciones de dominio de las intervenciones del conde de Barcelona, como los molinos y hornos en Siurana o Prades (1153/1159); o hornos, mercados y justicias en Duesaigües (1155) para recordar algunos ejemplos, que contrasta significativamente con la pluralidad de entradas derivadas del ejercicio de la justicia de la infeudación del Tallat (1147). En la encomienda de Barberà se descubre un programa de intervención señorial cuyo objetivo era incorporar todos los molinos de su territorio a su jurisdicción. Esto ilustra el interés señorial para disponer de un mecanismo útil en la obtención de recursos y en el control de la producción campesina, puesto que el señor podía obtener terciam partem de moltura, Col.lecció, pp. 178-9. Justamente en el período de establecimiento de los templarios, se multiplicaron los donativos de molinos a la encomienda: como la de Guillem de Claramunt (1170); la de Ferre de Llindars (1171): la de Gombau Oluja (1173); la de Guillem de Montfalcó (1186), quien a su vez ya había señorializado el molino de Cocard, Col.lecció, pp. 141-2, 142-3, 145-6, 206-7 y 205-6, respectivamente. También la encomienda hospitalaria de Alguaire obtuvo molinos en la primera etapa de definición señorial, ALturo, J.: Diplomatari d'Alguaire i del seu monestir santjoanista de 1076 a 1244, Barcelona, 1999, pp. 92-3 y 96-7. 
nes afectó igualmente a la renta territorial. Las nuevas condiciones socioeconómicas influyeron en una nueva fijación de ésta, como se refleja en una concordia entre los señores y los explotadores que preveía un incremento del pago en caso de que aumentasen las tierras de regadío, y por tanto la producción ${ }^{126}$.

Otros elementos contribuyeron a la transformación del sistema de prestaciones, como el dinamismo en las relaciones de posesión, que fue substituyendo al que había marcado el régimen de propiedad hasta estas fechas. En estos momentos se produjo una definición de señoríos que fue bastante estable en siglos sucesivos, y por esto empezaron a proliferar fórmulas de control o obligaciones económicas que salvaguardaban y afianzaban los derechos del propietario. Así, los señores impusieron mecanismos para asegurarse la titularidad de las tenencias cedidas en su señorío, como las fórmulas que impedían «venderla» a clericos y milites, la fijación del derecho de compra preferente y la consolidación del censo, entendido como el pago anual por la disponibilidad de las tierras ${ }^{127}$. Sin embargo, la definición contractual de las condiciones del teniente comportaba también el progreso en la estabilidad de sus derechos, que constituían los elementos básicos del establiment, convirtiéndose desde entonces en un instrumento fundamental en la definición de los términos de explotación y transferencia.

Además, el desarrollo de esta modalidad contractual y de otras instituciones conducentes a reforzar la vinculación de las tierras con el señor o el teniente, se explica en el contexto de expansión del mercado de la tierra. La conquista puso en circulación una cantidad de explotaciones hasta entonces desconocida, seguramente de dinero andalusí, se instaló en ciudades con mercado, generó expectativas de negocio y en definitiva estimuló la comercialización de los derechos de tenencia ${ }^{128}$.

126 El acuerdo afectaba a la satisfacción de la renta en especie que era una primera respuesta a la conversión en regadío, pero además y como se ha indicado se establecían otras condiciones en caso de ampliar el regadío y reflejaba como los señores perseguían beneficiarse de los incrementos de producción: et si ipsam honorem crescebat in regano crescite nobis nostrum censum similiter per racione, Col.lecció Gardeny, p. 368, (1173). El proceso negociador culminó en otros acuerdos, como la conventio que fijaron el Maestre del Temple y Randulfo de Sanahüja, quod omnibus annis quarta pars de expletis vinearum et XXti solidos, ACA, ORM, 193, f. 34v (1166). A veces el pacto surgía tras el cambio de titular en el señorío; como Ramon de Briançó quien asumió la dependencia con la encomienda templaria de Barberà y un nuevo censo, liberándose de las prestaciones en trabajo y el censo que hasta entonces pagaba a Gombau Oluja, Col.lecció, pp. 196-7, (1183).

127 Sin abundar en las múltiples previsiones señoriales para salvaguardar la propiedad de la tierra cedida, recordamos una que prohibía cambiar de señor al teniente, Col.lecció Gardeny, pp. 2712 (1166).

${ }_{128}$ No podemos avanzar más en esta cuestión que constituye un tema objeto de un estudio monográfico, pero cabe destacar que los cartularios del Temple de Gardeny y Tortosa están llenos de transacciones de este mercado de los bienes inmuebles, así como la documentación de Barberà o Poblet. En el caso de Tortosa, A. Virgili ha inventariado un total de 233 operaciones de compraventa, aunque destaca las necesidades de los colonos como una motivación importante a la hora de vender: Ad detrimentum, pp. 153-173. Así, recoge varias referencias a las contingencias de hambre y 
Entre los nuevos elementos de los contratos agrarios destaca la consolidación del censo, que representaba las obligaciones económicas del teniente por la parcela, aunque como se ha visto no se correspondía a la renta agraria satisfecha por el campesinado ${ }^{129}$. En realidad los contratos de cesión de tierras, y de forma cercana las cartas de población, tenían como función fijar la relación entre señores y tenientes de la heredad y, por tanto, su objetivo no era detallar todas las obligaciones o rentas, sino sólo aquellas más significadas del reconocimiento de señorío, o incluso algunas que se exigían a todos en las cartas de población.

Un tema fundamental es saber quienes eran los destinatarios de los citados contratos agrarios, que no se puede desligar de la parcialidad de su información. Como se ha visto, alguna vez se distinguía a sus beneficiarios de quienes deberían trabajar esas tierras, lo que explica que los destinatarios de las cartas de población o de los pactos a censo fuesen considerados probihomines en ocasiones. Así, los recipiendarios de la carta de población de Avinselo eran XX probis hominibus, y el mismo término de probi homines figuraba como genérico de los receptores de una concesión de tenencias a censo de huertos de Gardeny, que

necesidad de los vendedores. Sin embargo, y sin cuestionar estas dificultades pensamos que podían vender porque existía una cierta demanda, es decir que ese mercado estaba en expansión. En Lleida, hemos documentado a algunos personajes beneficiados o dedicados a negocios vinculados con la transmisión de tierras, a la gestión de la explotación, y que eran miembros de un colectivo que empezó a «enriquecerse» a partir de la subsidiariedad respecto a los señores.

129 Ya se ha indicado que se exigía el censo y además una renta de la tercera parte de los cereales a Ramon y Juan de Coscol. A veces, la cesión indicaba que junto a la satisfacción del censo, se debía el diezmo y la primicia, Col.lecció Gardeny, pp. 301-2, (1168); o en Tortosa sólo el diezmo: PAGArolas, L.: op. cit., pp. 243-4 (1180). En un balance de censos de Gardeny, sólo en una ocasión se recordaba que un teniente debía satisfacer un censo en metálico y los diezmos y primicias de la heredad, y en cambio estos últimos no se mencionaban en el resto de registros aunque presumiblemente también los pagaban, Col.lecció Gardeny, II. pp. 1070-1071. Asimismo en la renegociación del censo efectuada por Ramon de Brianzó al cambiar de dependencia señorial no se refiere el diezmo entre sus obligaciones económicas, pese a que el antiguo señor se lo reservó vitaliciamente cuando renunció a sus derechos, Col.lecció, pp. 197-198. Sin embargo y aunque los diezmos y primicias no siempre se especificasen en los documentos de cesión, su pago parece bastante incuestionable. Tampoco debemos generalizar su percepción a todo el campesinado, puesto que en alguna ocasión el señor los conmutaba como en una cesión a censo et non donetis inde nobis decimum et primiciam nec allium censo nisi solummodo in unoquoque anno IIIIr morabetinos, Col.lecció Gardeny, pp. 235-235 (1163). Esto es un testimonio más del proceso de negociación en la definición de las rentas, y a su vez de la variabilidad de situaciones. Con todo, el censo se solía singularizar en las descripciones de rentas, como en la donación de un hombre et omnes census, et usaticos et questias et ademprivos, Col.lecció Gardeny, p. 454 (1177), aunque este trato individualizado no fue obstáculo para que en algún arreglo de rentas se fijase una cuota o censo en vez de una renta u otra como el diezmo. Así la nueva exigencia fundía dos cánones antes diferenciados como los 25 sueldos que satisfaría Ramon de Sant Jaume al Temple en vez del diezmo y censo: XXV solidos pro decima et quarto per censum, Col.lecció Gardeny, p. 189, (1159). Además en esta ocasión la renta se convertía en monetaria cuando antes se pagaba en partes de cosecha — $1 / 4$ y $1 / 10$ - 
se reseñaban con nombre y apellido ${ }^{130}$. Su posición social destacada o privilegiada dentro del campesinado se desprende del trato como prohombres dispensado por la orden y de otros indicios, que se confirma porque algunos no trabajaban su tierra, siendo sólo intermediarios. De este modo, Joan Anglés reunió posesiones que por la distancia entre ellas y por las dimensiones del conjunto no podía trabajarlas todas y además en una cedida a censo por el monasterio de Santes Creus, se aclaraba quos nos laborant Azmet Abinforra et Abdalà, seguramente para que siguiesen siendo los trabajadores ${ }^{131}$.

El vacío que iban dejando las relaciones feudovasalláticas en sentido estricto, se fue remplazando por nuevas modalidades contractuales, que vinculaban a nuevos dependientes por la tenencia de la tierra, quienes a veces procedían de grupos destacados del campesinado, no siempre trabajadores de sus posesiones, y otras veces eran sólo labradores. A cambio, los principales señores consolidaron sus grandes dominios, y generaron mecanismos para mantener la integridad de sus patrimonios en una época caracterizada por el dinamismo en la disponibilidad de la tierra.

Desde muy temprano, la orden del Temple desarrolló en Lleida un plan exhaustivo para mantener o poner en marcha la explotación de sus bienes, que se tradujo en varias concesiones colectivas de tenencias a censo en la periferia del ámbito urbano, y otras individuales durante las dos primeras décadas de ocupación $^{132}$. En el primer grupo de cesiones de tierras de huerta de 1161 se

${ }_{130}$ Cartas, pp. 169-70 (1161); Col-lecció Gardeny, p. 273 (1166) y p. 288 (1167). Algunos de los beneficiarios figuran en otros documentos como tenientes, confirmantes, o implicados en transacciones ligadas al mercado de la tierra, y por tanto destacaban entre los suyos. Así Bernat Ferrer daría nombre a un distrito de torre donde había muchas unidades de explotación en manos de otros, que muestra su posición destacada en la nueva organización territorial, y Pere de Sanahüja hizo un «subestablecimiento» de lo obtenido en 1161, por el que se embolsó 28 sueldos, que es una cifra notable respecto de los 2 sueldos anuales de censo, Col-lecció Gardeny, II, p. 1067 y I, p. 291 (1167), respectivamente. Además Pere de Sanahüja confirmaba distintos documentos de Lleida, incluso en uno concedido por el conde de Urgell constaba como propietario de una tierra, que a su vez había comprado y vendía al Temple, Col-lecció Gardeny, pp. 424-5, aunque después dispuso de una parcela en la misma zona de Fontanet, Col-lecció Gardeny, p. 450 (1176), y anteriormente de otra distinta, Col-lecció Gardeny, p. 268 (1166).

${ }^{131}$ Las concesiones fueron efectuadas por el cenobio de Santes Creus: un honor en Cherta, LBSC, p. 179, (1174); unas casas en Tortosa a censo, LBSC p. 286, (1174); otra de un honor LBSC, p. 338, (1187); y en una a censo en Aldover, cultivado por los musulmanes dependientes referidos, LBSC, p. 338, (1190).

${ }_{132}$ Como ha advertido Forey, A.: op. cit., p. 205 la ocupación cristiana en Lleida tuvo continuidad desde mediados del XII, quien la contrasta con el fenómeno en las tierras del Ebro, donde no fue tan temprano. Tal y como se ha comentado, la reocupación de las dos ciudades fue especialmente cuidada por su valor estratégico y económico. Además, nos aventuramos a plantear que el hecho que en Lleida hubiese un ámbito cercano feudalizado desde décadas atrás ayudó a esa rápida reocupación, tejiendo un mayor continuo poblacional en su ámbito territorial que en el de las tierras meridionales catalanas, pese a la también rápida ocupación de Tortosa. La región dertosense no contó con ese espacio circundante cercano que podía aportar gentes a modo de efecto cascada. 
fijaron los censos a razón de un sueldo por fanega, ajustándose a las dimensiones de las tierras y por un período de cinco años, y en 1166 se produjo otro grupo de cesiones a censo en el mismo ámbito ${ }^{133}$. Esto muestra un planteamiento de la economía señorial organizado y contable, que concuerda con la exigencia del censo en metálico en buena parte de este tipo de contratos. Es posible que los templarios buscasen la obtención de unos ingresos estables, aunque el objetivo era ante todo asegurar la continuidad de unas formas de explotación andalusíes, a menudo de regadío, ya fuese huerta o no, que era fuente de riqueza en otros sentidos.

Algunos señores como los templarios buscaban unos ingresos en numerario, lo que no debe interpretarse mecánicamente como una monetarización de la economía, puesto que la renta en especie seguía siendo fundamental para muchos poderes feudales, como lo era a su vez en Gardeny. En otros dominios, la exigencia del censo en cuota fija se hizo en especie como en el dominio del Ebro de Santes Creus, aunque alguna reclamación se establecía en dinero ${ }^{134}$. También en la región de la retaguardia de la conquista se desarrolló un sistema mixto, en el que había censos reclamados en especie y otros en dinero ${ }^{135}$. Como es natural, no había un sistema unitario en la exacción de las rentas, tanto por la diversidad de las relaciones que se establecían entre señores y tenientes, co-

133 Col.lecció Gardeny, pp. 212-213 y pp. 273-274 respectivamente. No sabemos si los nuevos tenientes remplazaban a los primeros puesto que la prescripción de cinco años y en el mismo lugar así lo indicarían. No obstante, el hecho que los beneficiarios fuesen menos, todos diferentes y las rentas distintas pero acordes con los mismos parámetros de 1161 indican que se trata de un proceso de ampliación. Otras concesiones a censo de Gardeny a título individual, Col.lecció Gardeny, pp. 2345; 271-2 (1166) — que ya había sido de otro teniente—; y otro a tres, pp. 262-3 (1165). Sin embargo, también se produjeron peticiones de censo en especie e incluso en trabajo por parte de los templarios de esta encomienda, como hiciesen a la comunidad de Avinselo: et faciatis nobis censum per unumquemque annum ...I perna de carn de XV denaris...et IIII fogazas et I iornal in ipso dominico ...et I tragin usque ad Ilerdam, Cartas, pp. 169-170. El trayecto hacia Lleida no era poca cosa desde el Priorato donde hemos localizado este lugar. En las cartas de población concedidas por Armengol VII las exigencias en concepto de censo se parecían a estas, aunque con peticiones de cereales y sin prestaciones en trabajo.

${ }^{134}$ Entre las reclamaciones de censo en cosecha, citamos los seis cántaros de aceite (1159), otros 14 (1170); los 8 (1174) o las III somatas...vindemia (1188), LBSC, pp. 87-88, 144-5, 181, 307. En cuanto a las exigencias de renta en moneda en los mismos lugares de Cherta y Tortosa constaban los 18 sueldos (1174) o los 10 morabetinos (1176), LBSC, pp. 179 y 190 respectivamente. En la cesión a censo de 1174 reclamado en aceite se precisaba et si forte evenerit in istam terram talem gueram sarracenorum quod non possitis recolligere omnibus expletis...convenimus adlaxare de predictum censum. La cita es interesante puesto que informa del clima en que se vivía en las primeras décadas de ocupación cristiana, que era de una cierta excepcionalidad, y puede relacionarse con que la recolección fuese llevada a cabo por musulmanes, que si fallaban por rebelión podían perjudicar los intereses de los intermediarios.

${ }_{135}$ En la transferencia de los derechos dominicales de Arnau de Su al Temple de Barberà se refleja la convivencia de censos en metálico y en especie, Col.lecció, pp. 160-1 (1175). Un censo de 1163 contemplaba el pago de perna I et fogaças IIII et quartera I de civada... y otro del mismo dominio era de dos sueldos, Col.lecció, pp. 131 y 156. 
mo por los intereses señoriales. La disponibilidad de entradas regulares en dinero ya era una necesidad, pero la de recursos en especie una garantía y una posibilidad para la intervención en el mercado, que explicaría la reclamación en cántaros de aceite en el dominio del Ebro de Santes Creus.

Otro tipo de tratos entre señores y tenientes — administradores - comportaban la retención de una parte de la producción por parte del propietario, y que son diferentes a las concesiones a censo. Esta modalidad de acuerdo derivaba de los pactos feudovasalláticos, como se ha analizado en las concesiones a partes efectuadas por el escriba Ponç en Lleida, y en una de ellas se distinguía específicamente el censo de la parte proporcional de la cosecha que retenía como señor ${ }^{136}$. Además, la palabra censo se diferenciaba de la porción reservada por el señor, definida a veces como retención o reserva ${ }^{137}$. El censo marcaba la disponibilidad del teniente o dependencia con el titular y la porción de cosecha definía la cesión o participación de la propiedad.

Diversas modalidades de repartos de beneficios caracterizaron esta fórmula de gestión, que seguían las proporcionalidades de las retenciones señoriales de las Marcas, como eran la tercera parte, la cuarta, la quinta o incluso la mitad, aunque en esta nueva clase de pacto los distintos conceptos de entrada de las mencionadas retenciones se habían fundido en un único objetivo que era la mera participación en las cosechas. Además, los propietarios exigían a los beneficiarios trabajar, mejorar o plantar determinadas producciones, y estas reclamaciones habían ido substituyendo a las funciones militares o incluso judiciales que obligaban a los vasallos en las Marcas e incluso en Tarragona ${ }^{138}$.

${ }^{136}$ En otro instrumento de Balaguer se diferenciaba claramente el censo de la parte retenida por el señor: in tali vero conventu que donetis vos et vestras... quartam partem de quale fructum exierit de ipso alaudio...et faciatis censum per unumquemque annum porcus qui valet VI solidos o VI solidos...et XII fogaces bones de pane et I solido de vi et IIII fanneces de civada, Diplomatari, p. 130 (1152).

137 Algunos autores han identificado estos instrumentos con concesiones a censo, como puede verse en los regestos de los documentos de la edición del Llibre Blanch de Santes Creus, de F. Udina o en Diplomatari de Tortosa de A. Virgili, y en su estudio relativo a la prestaciones campesinas $A d$ detrimentum, pp. 181 y 194-5.

${ }^{138} \mathrm{La}$ retención de la cuarta parte de los frutos figura en algunas de estas concesiones, PAGAROLAS, L.: op. cit., p. 190 (1163) o LBSC, pp. 316-317 (1188), en las que podía incrementarse la proporción de otros cultivos como del vino o del aceite, que eran apreciados en el mercado, Diplomatari Tortosa, p. 88 (1153), y pp. 105-106 (1155), aunque también en una ocasión se reclamaba la mitad de la cosecha y la cuarta parte del aceite, $L B S C$, p. 179 (1174). A veces se exigía un tipo de cultivo, ...et plantetis olivaris et quartam partem olei tributatis, LBSC, p. 286 (1187), y otras el trato era muy ventajoso para el donante, como Narbona e hijo que se reservaron dos terceras partes, Diplomatari Tortosa, pp. 171-2 (1162). Otros acuerdos eran más complicados, en la medida que ya eran compraventas de anteriores donaciones a proporción, como la efectuada por Pere de Abella y esposa que comprometía el pago de la quinta parte de la vendimia y frutos a Ramon Montpeller, y después la mitad de frutos, vendimia, cañas y madera a Berenguera, Col.lecció Gardeny, pp. 268-9 (1166). En cuanto a las actividades exigidas a los beneficiarios se encuentran frases como ad laborandum..., ad plantandum..., y en una concesión de unas tierras a un colectivo en Conesa, a la previsión de la puesta en explotación de una pieza se fijaba la cuarta parte para los señores, 
En general, estas concesiones con retención de rentas afectaban a entidades patrimoniales grandes o notables a diferencia de las unidades sujetas al pago de censo que solían ser menores ${ }^{139}$. En las explotaciones concedidas con participación de beneficios, los administradores empleaban a otros trabajadores, de lo que daba cuenta Ponç cuando comprometía a su aprobación la elección de los labradores por parte del administrador, o en ocasiones se indicaba que el pago de las obligaciones comprometía a vos et vestri qui pro vos habuerit..., adviertiendo de la delegación en la explotación, pese a que pueda tener connotaciones genéricas ${ }^{140}$.

Por tanto, y a la vista de lo anterior, cabe preguntarse quiénes trabajaban la tierra o pagaban la renta finalmente, o qué pagaban. Nuestro conocimiento sobre la realidad campesina es muy sesgado, y los contratos analizados trababan dependencias que no siempre finalizaban explícitamente en la base de los productores de la sociedad. Las noticias disponibles sobre los trabajadores agrarios en un sentido estricto son insignificantes respecto a toda la trama de relaciones vista. Sabemos de la existencia de algunos exáricos musulmanes, o simplemente labradores musulmanes y judíos, otros laboratores, algunos donados que cultivan o pueden explotar sus antiguas propiedades, y existe algún documento excepcional como el de Gardeny relativo a los «servicios» que hacen los hombres stantibus in Sigriano ${ }^{141}$. Una vez más la organización de la contabilidad templaria es un testimonio de las nuevas economías señoriales.

La descripción no deja duda de la condición de campesinos de los que «están» en el ámbito del Segre, cuantificándose sus pagos en especie junto a alguna prestación en trabajo. La relación de los mencionados servicios se agrupaban por torres bajo el «dominio» o control de algún intermediario, quizás su primer propietario cristiano, que como hemos comentado debía reproducir la organización andalusí, o al menos territorial de los ámbitos dependientes de las to-

\footnotetext{
omitiéndose las obligaciones exigidas en las ya cultivadas, Col.lecció, pp. 195-6 (1182). Por tanto, la preocupación era favorecer la explotación, asegurándose a su vez los beneficios. El recordatorio a las convenientiae aparece en el léxico, in tale conveniencia, en la estructura de dos partes de los compromisarios, en exigencias un tanto particulares a la fidelidad et ut tu sis nobis fidelis laborator. El señor imponía garantías de cara a la recuperación de la titularidad, ya fuese fijando un periodo de explotación, aunque bastante ocasionalmente, o con la fijación de la fadiga y el laudemio.

${ }^{139}$ La mayor entidad de las tierras se deduce de su calificación como honores o a almunia, así como a la diversidad de cosechas que se detallan en su mayoría, LBSC, p. 179 (1174), Diplomatari Tortosa, pp. 187-188; pp. 279-180 (almunia). De las dimensiones menores de parcelas establecidas a censo disponemos de medidas concretas en la huerta de Gardeny, que tenían una, dos y tres fanegas.

140 Además al igual que en los administradores de las tierras a censo, los beneficiarios eran personas acomodadas y con trabajadores a su cargo, como Joan Anglés, o Barrufet de Riquer, quien obtuvo varios bienes en Albió sujetos a pagos de la cuarta o quinta parte y quien había hecho «establecimiento de honores», que expresa como había derivado la explotación hacia otras personas: fecit donum et stablimentum onoris, Col.lecció, p. 175 (1178).

${ }_{141}$ Col.lecció Gardeny, II, pp. 1065-1069. Tal y como apunta SALRACH, J.M.: La renta, p. 65, los servicios se transformaron en censos señoriales, a menudo relacionados con la explotación de la reserva. También hemos visto que en alguna ocasión el término se utilizaba simultáneamente para las prestaciones vasalláticas y las campesinas.
} 
rres. El documento carece de fecha, como si estuviese aludiendo a unas obligaciones atemporales y ya no hay condiciones, sino sólo obligaciones. Así, es bastante común el pago de renta en cereal, repartida en trigo, cebada y avena, de una jova y una tragina — prestación de labranza y de transporte-, que se relacionan de nuevo con la extensión de la parcela. El inventario sólo reflejaba los servitia por la disponibilidad de la tenencia, por lo que carecía una vez más de menciones a otras rentas que debían satisfacer, como diezmos y primicias, que seguramente pagaban como hacían los habitantes de Lleida.

De todas maneras, cabe observar que si bien el sistema de prestaciones era dinámico, y adaptado a las circunstancias o negociaciones, no es menos cierto que se aprecia un proceso de ordenación, fijación, y en cierto modo simplificación perseguido desde las economías señoriales. Sirva como testimonio la definición de la renta de la tasca en el territorio de Tarragona en 1173, que atribuyó la percepción de cuatro cuarteras de cereal por yugada a los baiulos del rey y del arzobispo y de las que finalmente el monarca obtendría tres y el arzobispo la cuarta, salvo en su dominicatura ${ }^{142}$. Esta estandarización de una renta proporcional a las tierras en explotación contrasta con la tasca en la región de Tortosa que era la onceava parte de las cosechas.

Las cantidades exigidas en Tarragona por la tasca reaparecían en sendas cartas de población de Montroig (1180) y de Reus (1183), a las que se agregaba una cantidad de vid, la exigencia de los monopolios del horno o de la herrería, y en Reus la carga de diezmos y primicias o la obligación de fortificar, donde los señores se comprometían a no pedir más, renunciando a la fuerza y violencia ${ }^{143}$. Pese a la coincidencia de la renta en especie con la tasca de Tarragona, no se reclamaba como tal, e incluso en Montroig se identificaba como censu pariliatum, pero se precisaba que la correlación con la tierra se hacía para que: ut qui plus babuerit plus donet et qui minus habuerit minus donet. Esto da cuenta que aparecía un remoto principio de equidad en la fijación del canon, y por otra parte confirma como determinadas rentas como la tasca o el censo funcionaban como mecanismos para el reconocimiento del señorío o de la dependencia.

En definitiva en las décadas posteriores a la conquista se produjo una enorme transformación en la definición de las propiedades dominicales mientras se dinamizaban las relaciones de posesión, o al menos se regulaban como nunca se había hecho. De los cambios en la propiedad y posesión se derivaron otros sociales, que se reflejaban en la parálisis de las viejas dependencia militares o el surgimiento de nuevos grupos sociales, y que además condicionaron la renovación del sistema de prestaciones económicas, todo ello en un contexto de crecimiento económico. El sistema antiguo y heterogéneo de derechos o pagos fue simplificándose en beneficio de otro que ante todo perseguía participar de los beneficios de la producción agraria, reduciendo entradas, y por tanto se presumía más operativo. Sin embargo las novedades no alteraron aspectos tan

\footnotetext{
142 BLANCH, J.: op. cit., pp. 108-109.

${ }_{143}$ Cartas, pp. 220-1 y pp. 236-7.
} 
definitorios de la realidad feudal como el reconocimiento del señorío, ya fuese mediante la declaración de dependencia o de la satisfacción de rentas concretas que eran emblemáticas de la vinculación personal.

\section{EPÍLOGO}

Las dependencias personales en la Cataluña Nueva se transformaron a tenor de la gran expansión catalana a mediados del siglo XII. En las regiones de las Marcas, e incluso en la de Tarragona, se aceleró la fijación de dependencias vasalláticas en vísperas de las conquistas y poco después, con un propósito militar y de consolidación del poblamiento. El resultado fue la división de poderes y beneficios, creándose una compleja trama jerárquica de vinculaciones personales.

Tras las conquistas se definieron otras fórmulas de intervención señorial, como las de los condes en los ámbitos referidos y especialmente en los conquistados, que establecían relaciones de los dependientes con su persona de forma exclusiva e involucraban a distintos segmentos sociales antes subestimados. Los señores también se reservaron en exclusiva algunas rentas cuya función era manifestar el reconocimiento de señorío, ya fuese la novena, el diezmo, o incluso el censo con posterioridad, mientras que en la fase anterior el diezmo con idéntico uso se había compartido.

La centralidad del poder señorial respecto de los dependientes, como la posición central de las ciudades conquistadas en sus regiones desbancaron la anterior atomización de parcelas de poder, del mismo modo que la recomposición simplificadora del sistema de prestaciones desplazaba al complejo y arbitrario precedente. Así la máxima «quien más tenga que pague más» aparecía cuando empezaban a rechazarse los pagos por la fuerza, y un incipiente sentido de la justicia, la pacificación o la racionalización contribuían a la renovación de la organización feudal.

Algunos señores como los vasallos militares perdieron protagonismo, pero otros se hicieron más poderosos como los principales del Camp de Tarragona, o las órdenes religiosas y militares que alcanzaron dominios espectaculares a través de un complejo fenómeno de redefinición patrimonial. La consolidación de estos grandes conjuntos dominicales coincidió con la dinamización del mercado de la posesión de la tierra, y en cierto modo la ruina de algunos terratenientes con el surgimiento de los embriones de las oligarquías rurales.

Todo esto sucedió cuando se produjo la conquista de las tierras andalusíes, en las que se impuso un sistema social más elaborado para alcanzar el dominio o mantener las formas y ritmos de explotación. La excepcionalidad determinó la fijación de relaciones más pacíficas en la vanguardia, aunque la belicosidad feudal terminó por exigir otras en la retaguardia. Y pese a la cara más amable de la nueva realidad social, los poderes feudales eran más activos en la exigencia de vinculaciones personales o en la participación de los beneficios económi$\cos$, cuyas soluciones fortalecieron y renovaron el sistema feudal. 


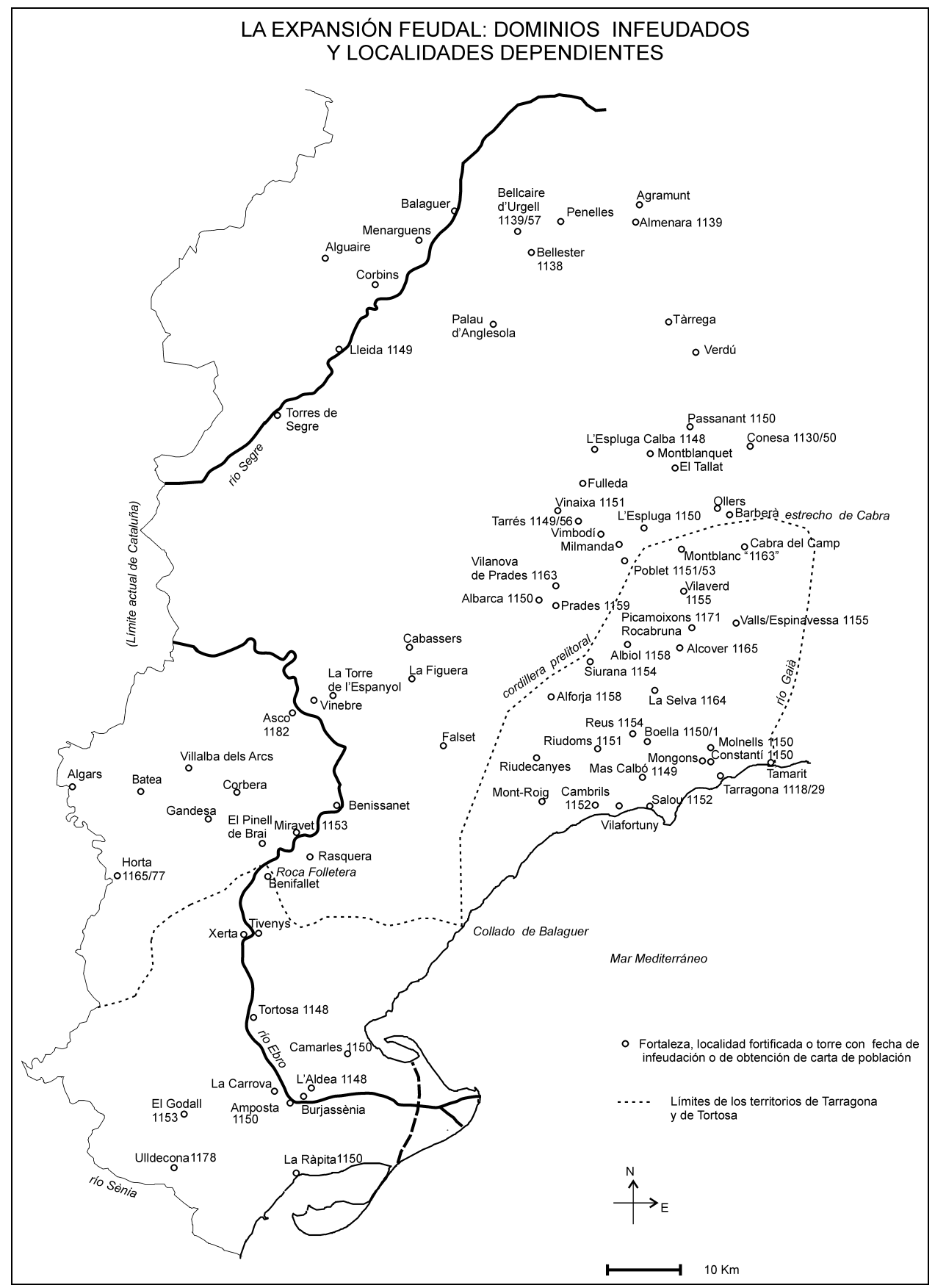

Hispania, 2006, vol. LXVI, nº. 223, mayo-agosto, 425-482, ISSN: 0018-2141 